AperTO - Archivio Istituzionale Open Access dell'Università di Torino

\title{
Peptide conjugation: before or after nanoparticle formation?
}

\section{This is the author's manuscript}

Original Citation:

Availability:

This version is available http://hdl.handle.net/2318/157810

since 2017-05-16T16:31:03Z

Published version:

DOI:10.1021/bc5003423

Terms of use:

Open Access

Anyone can freely access the full text of works made available as "Open Access". Works made available under a Creative Commons license can be used according to the terms and conditions of said license. Use of all other works requires consent of the right holder (author or publisher) if not exempted from copyright protection by the applicable law. 


\section{(6) \\ UNIVERSITÀ DEGLI STUDI DI TORINO}

This is an author version of the contribution published on:

Questa è la versione dell'autore dell'opera:

Bioconjugate Chemistry, 25(11), 2014, doi: 10.1021/

The definitive version is available at:

La versione definitiva è disponibile alla URL:

http://pubs.acs.org/doi/abs/10.1021/bc5003423 


\section{Peptide conjugation: before or after nanoparticle}

\section{formation?}

Sabrina Valetti, ${ }^{\S, \phi}$ Simona Mura, ${ }^{\S}$ Magali Noiray, ${ }^{\S}$ Silvia Arpicco, ${ }^{\phi}$ Franco Dosio, ${ }^{\phi}$ Juliette Vergnaud, ${ }^{\S}$ Didier Desmaële,,$^{\S}$ Barbara Stella, ${ }^{\phi, *}$ Patrick Couvreur ${ }^{\S}$

${ }^{\S}$ Université Paris-Sud, Faculté de Pharmacie, 5 rue Jean-Baptiste Clément, 92296 ChâtenayMalabry cedex, France

CNRS UMR 8612, Institut Galien Paris-Sud, 5 rue Jean-Baptiste Clément, 92296 ChâtenayMalabry cedex, France

\$Dipartimento di Scienza e Tecnologia del Farmaco, Università di Torino, 9 via Pietro Giuria, 10125 Torino, Italy

*To whom correspondence should be addressed.

E-mail: barbara.stella@unito.it

Tel.: +390116706800

Fax: +39 0116706663 


\section{ABSTRACT}

We report herein a detailed study concerning the impact of different bioconjugation and nanoformulation strategies on the in vitro targeting ability of peptide-decorated squalenoyl gemcitabine (SQdFdC) nanoparticles (NPs). NPs have been functionalized with the CKAAKN peptide, previously identified as efficient homing device within the pancreatic pathological microenvironment. Two approaches have been followed: (i) either the CKAAKN peptide was directly conjugated at the surface of preformed SQdFdC nanoparticles (conjugation after NP formation) or (ii) it was first reacted with a maleimide squalenoyl derivative before the resulting bioconjugate was co-nanoprecipitated with SQdFdC to form the peptide-decorated NPs (conjugation before NP formation). NPs were characterized with respect to mean diameter, zeta potential and stability over time. Then, their specific interaction with the sFRP-4 protein was evaluated by surface plasmon resonance. Although both the synthetic strategies allowed to formulate NPs able to interact with the corresponding receptor, enhanced target binding and better specific avidity were observed with CKAAKN-NPs functionalized before NP formation. These NPs displayed the highest cell uptake and cytotoxicity in an in vitro model of human MIA Paca-2 pancreatic cancer cells. 


\section{INTRODUCTION}

The ability to selectively deliver drugs to tumor cells with minimal interaction with healthy tissues is a major challenge in chemotherapy. To this aim, suitable ligands able to bind to specific receptors, overexpressed on cancer cells and relatively downregulated on healthy tissues, have been successfully employed as a valuable strategy to specifically target tumors. ${ }^{1}$ By means of molecular recognition, such targeted therapy has improved the balance between efficacy and toxicity of conventional systemic anticancer treatments ${ }^{2}, 3$ as observed, for instance, in the case of antibody-conjugated chemotherapeutic agents. ${ }^{3-5}$ Several antibody-drug conjugates are currently included in clinical trials with encouraging results ${ }^{6}$ and two examples, Adcetris $^{\circledR}$ (Takeda, Seattle Genetics) and Kadcyla ${ }^{\circledR}$ (Roche, Genentech), have recently been approved by FDA and EMA. ${ }^{7-8}$

In parallel, the use of targeting ligands grafted to the surface of nanoscale drug delivery devices (i.e., nanomedicines) appears as another promising approach. ${ }^{9}$ Compared to molecular conjugates, nanocarriers offer the advantage to protect the drug molecule from degradation and to better control drug release. Moreover, by tuning the number of ligand molecules onto the nanocarrier surface, targeting efficacy might be improved via a multivalent binding process. ${ }^{10}$ In the past 30 years, a plethora of targeted nanoparticles functionalized with various ligands belonging to the families of small molecules, polysaccharides, peptides, proteins or even antibodies has been developed. ${ }^{11-12}$ Nanomedicines are gaining more and more attention in cancer therapy ${ }^{13-14}$ with 5 examples on the market and 10 in clinical development. ${ }^{15}$

However, not any ligand-decorated nanomedicine has reached the market and only 5 are currently in early clinical trials. ${ }^{15-16}$

Several functionalization strategies and coupling methods have been developed, each of them exhibiting benefits and drawbacks (for systematic review see ${ }^{11}$ ). In general, the targeting efficacy of a functionalized nanocarrier is governed by (i) the nature of the matrix and the 
ligand, (ii) the selected coupling reaction, (iii) the disposition of the ligand at the surface and (iv) the ligand surface density. ${ }^{17-22}$ Two main ligation strategies have been used to display the targeting agents at the surface of the nanocarriers: the ligand can either (i) be directly coupled in aqueous solution to the surface of preformed nanocarriers or (ii) be linked to the nanocarrier components prior to nanocarrier construction (Figure 1a).

The first strategy is generally preferred because the ligand is directly grafted onto the nanoparticle surface and available for the receptor recognition, whereas the linkage of bulky ligands (such as polypeptides, proteins or antibodies) to the nanocarrier building material might alter its hydrophilic/lipophilic balance and its self-assembly properties. ${ }^{11}$ An undeniable advantage of the second strategy relies on the possibility to control the reaction yield, to purify and characterize the resulting conjugate. However, the solubilization in organic solvents, that is sometimes required, could cause denaturation of the proteins or antibodies compromising their affinity for the receptor. In addition, in this approach the ligand is susceptible of entrapment into the nanocarrier core during nanoparticle preparation, leading to insufficient surface coverage and lower availability for interaction with the corresponding receptor. Therefore, a comparative study about advantages/disadvantages of each strategy should be done for any new system, in order to achieve successful actively targeted nanoparticles. 
a)

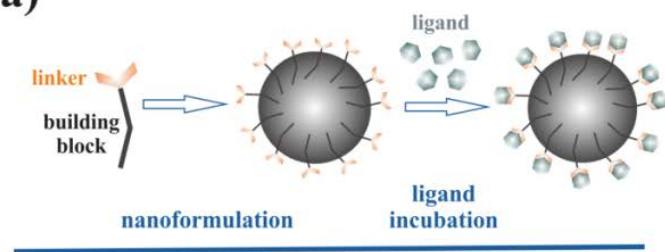

i) ligand coupling AFTER NP preparation

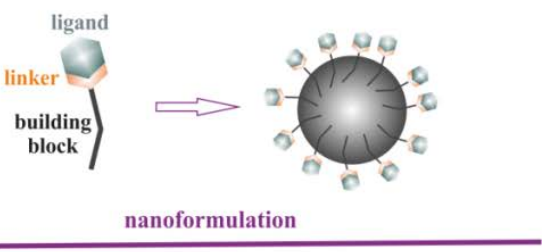

ii) ligand coupling BEFORE NP preparation

b)

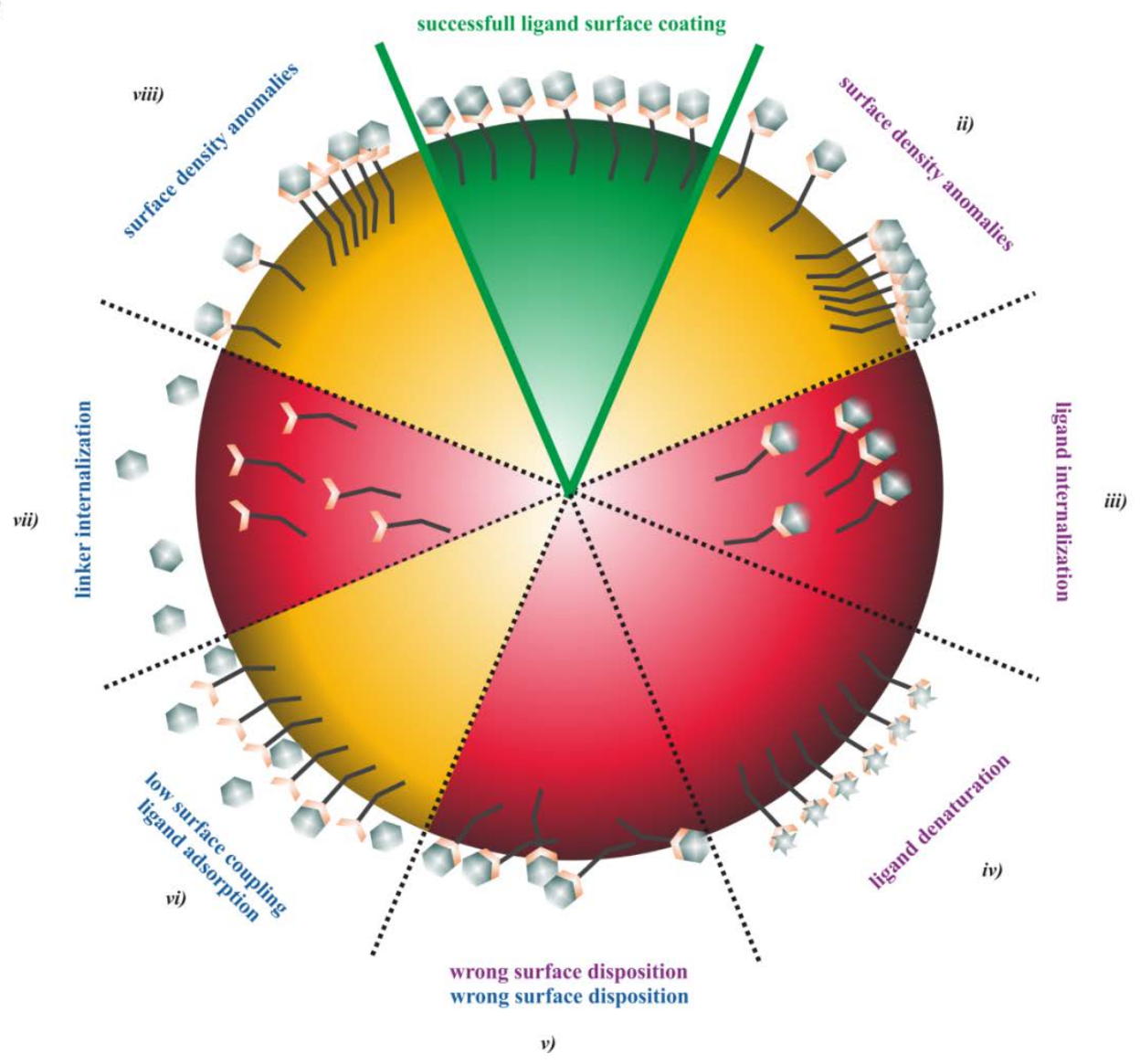

Figure 1. a) Strategies to prepare ligand-functionalized NPs: (i) the ligand can be coupled to the surface after nanoparticle formation or (ii) be directly conjugated to the nanocarrier building material prior to NP formation. b) Schematic representation of possible ligand disposition after both ligation strategies. Blue titles are referred to (i) ligand coupling after nanoparticle preparation and violet ones to (ii) ligand coupling before nanoparticle preparation. The green segment symbolizes the successful ligand coating, while yellow and red ones correspond to low and inefficient ligand disposition, respectively. 
In this study, we report a rational approach for the design of ligand-targeted squalene-based nanoparticles for specific drug delivery to pancreatic tumor cells. The "squalenoylation" approach consists in the chemical linkage of squalene (SQ), a natural triterpene precursor in the sterol biosynthesis, to biologically active molecules. The obtained lipid bioconjugates are able to self-assemble in aqueous solution to form stable nanoparticles with high drug payloads. ${ }^{23}$ Such innovative concept has firs been applied to gemcitabine (dFdC), which is the first-line therapeutic agent in pancreatic cancer treatment. ${ }^{24}$ After intravenous administration, 4- $(N)$ trisnorsqualenoylgemcitabine (SQdFdC) nanoparticles exhibited impressively greater anticancer activity than the free drug against different tumor models (e.g., experimental leukemia and pancreatic cancer). ${ }^{23,25-27}$ However, the physio-pathological complexity of pancreatic cancer ${ }^{28}$ urgently required the development of better targeted therapeutic approaches to enhance selective nanoparticle internalization by cancer cells, also avoiding potential side effects.

In this context, functionalized SQdFdC nanoparticles were prepared by linking the CKAAKN peptide, previously identified as efficient homing device within the pancreatic pathological microenvironment by phage display screening. ${ }^{29}$ These nanoparticles were found to be more efficient than non CKAAKN-functionalized nanoparticles on a transgenic mice model of pancreatic cancer. ${ }^{30}$ Herein, we performed a comparative study to establish the optimal CKAAKN peptide-SQdFdC nanoparticle ligation strategy. Briefly, CKAAKN peptide was conjugated to the nanoparticles by the well-explored thiol-maleimide Michael addition coupling strategy either (i) by reacting the targeting moiety with preformed nanoparticles obtained in accordance with the nanoprecipitation technique (Figure 1a - left panel) or (ii) by conjugating the peptide with a squalenoyl derivative before constructing nanoparticles by mixing the obtained bioconjugate with SQdFdC (Figure 1a - right panel). The resulting 
CKAAKN-SQdFdC nanoparticles were characterized with respect to size, zeta potential, stability, receptor binding affinity and in vitro targeting ability.

\section{RESULTS AND DISCUSSION}

Preparation and characterization of non targeted nanoparticles. In order to obtain stable CKAAKN-functionalized SQdFdC nanoparticles, the formulation of the colloidal system was deeply investigated by tuning the preparation conditions. In particular, a maleimide groupbearing squalene derivative (SQMal) able to link the peptide via its thiol function was added to SQdFdC (1) in various molar ratios. Moreover, two different spacers were introduced between the squalene moiety and the maleimide group. In the case of the SQMal ${ }_{\text {lipo }}(3),{ }^{30}$ a 6 -carbon atom lipophilic chain served as a spacer, while for the SQMal ${ }_{\text {hydro }}(\mathbf{4}),{ }^{31}$ a hydrophilic ether chain was inserted (Figure 2). 


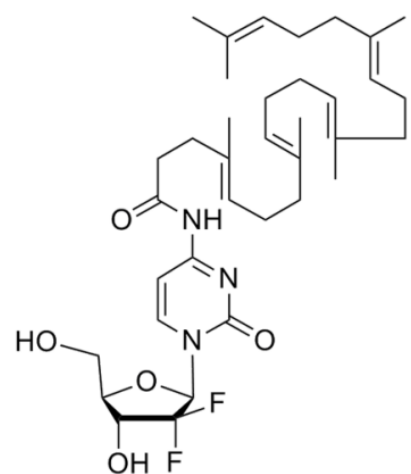

SQdFdC (1)

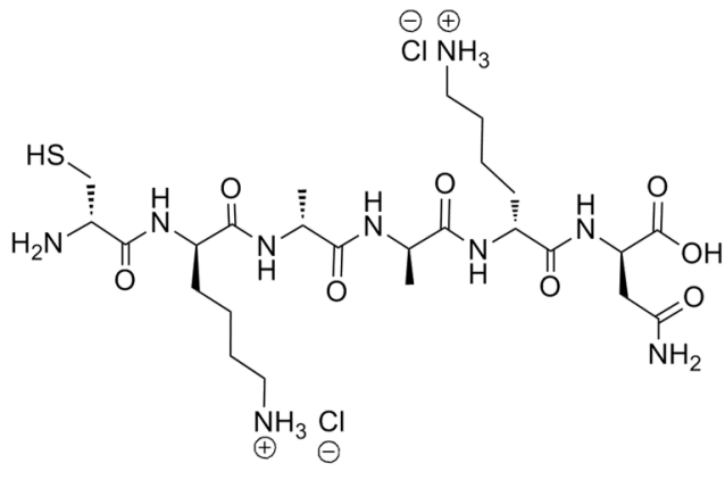

CKAAKN (2)
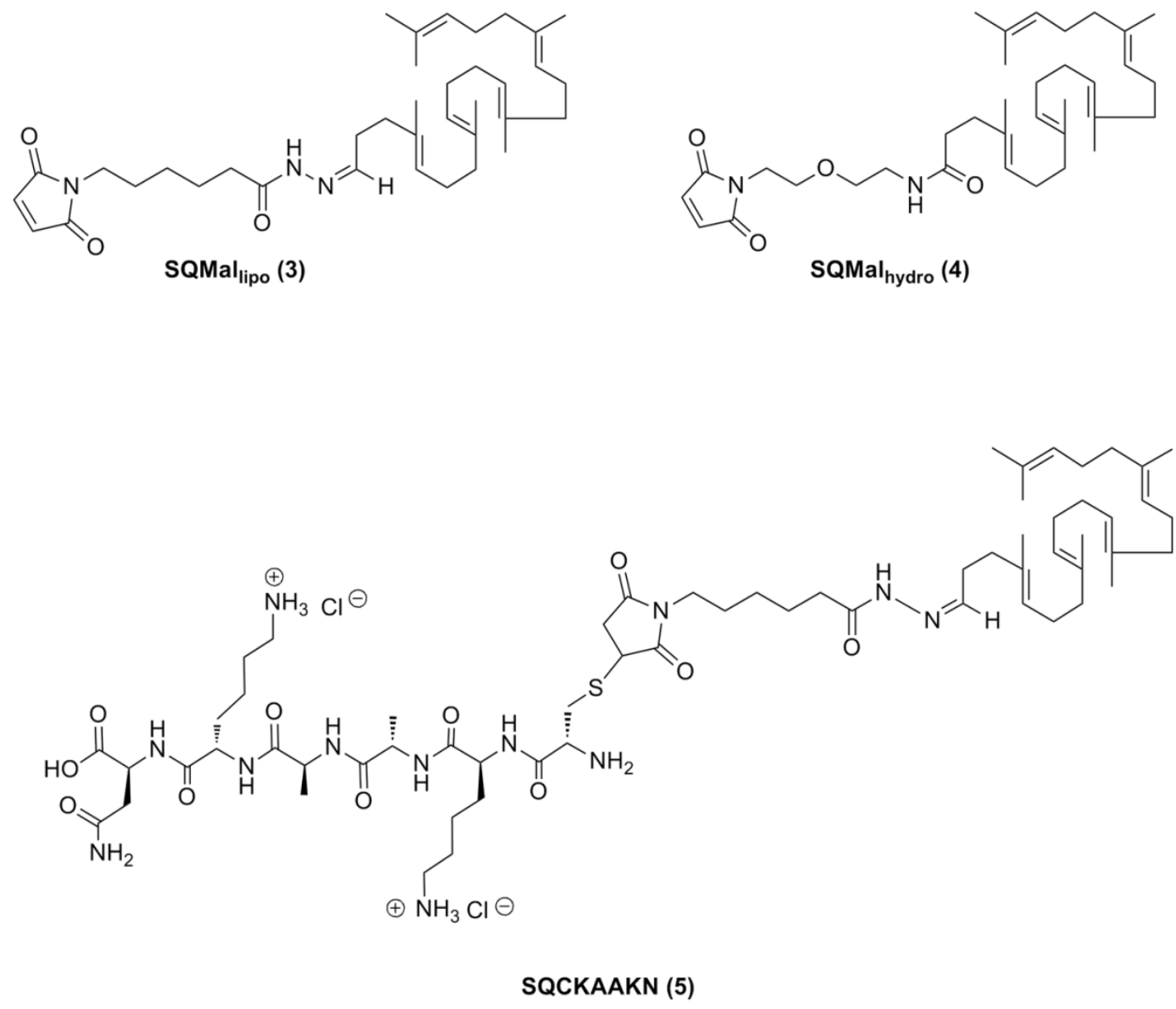

Figure 2. Structures of SQdFdC (1), CKAAKN peptide (2), SQMal ${ }_{\text {lipo }}$ (3), SQMal ${ }_{\text {hydro }}$ (4) and SQCKAAKN (5). 
All NPs were prepared by nanoprecipitation, using acetone or ethanol as organic solvent and without adding any surfactant. Maleimide-bearing SQdFdC NPs were prepared by adding SQMal ${ }_{\text {lipo }}$ or SQMal ${ }_{\text {hydro. }}$.

SQdFdC and SQMal ${ }_{\text {lipo }}$ were co-nanoprecipitated at various SQdFdC/SQMal ${ }_{\text {lipo }}$ molar ratios $(10: 1,5: 1,2: 1)$ with a constant SQdFdC concentration (either in acetone or in ethanol), giving a suspension of narrow monodispersed NPs (N1). Addition of SQMal lipo led to a slight size increase compared to SQdFdC NPs which displayed a mean diameter of $141 \mathrm{~nm}$ and $122 \mathrm{~nm}$ when prepared in acetone (N0a) or ethanol (N0e), respectively (Table 1).

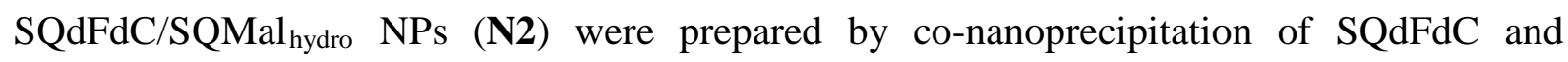
SQMal $_{\text {hydro }}$ at two molar ratios $(10: 1,5: 1)$, with a constant SQdFdC concentration. Ethanol turned out to be the best solvent, while when acetone was employed NPs instantly aggregated. As observed for SQdFdC/SQMal ${ }_{l i p o}$, N2e displayed a mean diameter of less than $200 \mathrm{~nm}$ and a narrow particle size distribution (Table 1). However, the presence of an ether chain between the maleimide group and the squalene moiety affected the nanoparticle stability, probably due to a modification of the internal inverted hexagonal phase structure of SQdFdC nanoparticles. ${ }^{32}$ On the contrary, a higher stability was observed when a lipophilic chain was used as spacer $\left(\mathrm{SQMal}_{\text {lipo }}\right)$.

According to these results, the SQMal ${ }_{\text {lipo }}$ was preferred to the SQMal ${ }_{\text {hydro }}$ for the preparation of peptide-targeted SQdFdC nanoparticles. Acetone was selected as solvent due to the higher colloidal stability of N1a nanoparticles compared to those prepared in ethanol (N1e). Using acetone as solvent and a low or medium amount of $\mathrm{SQMal}_{\text {lipo }}\left(\mathrm{SQdFdC/SQMal}_{\text {lipo }}\right.$ 10:1 or 5:1), no precipitation was detected after 1 -week storage at $4^{\circ} \mathrm{C}$. 
Table 1. Nanoparticle composition and characterization.

\begin{tabular}{|c|c|c|c|c|c|c|c|}
\hline NPs & $\begin{array}{l}\text { Solvent used in the } \\
\text { nanoprecipitation }\end{array}$ & Composition & $\begin{array}{c}\text { Components molar } \\
\text { ratio }\end{array}$ & $\begin{array}{c}\text { Mean } \\
\text { diameter } \\
(\mathrm{nm} \pm \text { S.D. })\end{array}$ & $\begin{array}{c}\text { Polydispersity } \\
\text { index }\end{array}$ & $\begin{array}{c}\text { Zeta potential } \\
\text { (mV } \pm \text { S.D.) }\end{array}$ & $\begin{array}{l}\text { Stability } \\
\text { at } 4{ }^{\circ} \mathrm{C} \\
\text { (days) }\end{array}$ \\
\hline NOa & Acetone & SQdFdC & - & $141 \pm 42$ & 0.087 & $-22 \pm 4$ & 3 \\
\hline Noe & Ethanol & SQdFdC & - & $122 \pm 8$ & 0.103 & $-22 \pm 5$ & 3 \\
\hline \multirow[t]{3}{*}{ N1a } & Acetone & SQdFdC/SQMal $_{\text {lipo }}$ & $10: 1$ & $164 \pm 42$ & 0.066 & $-27 \pm 3$ & 7 \\
\hline & Acetone & $\mathrm{SQdFdC/SQMal}_{\text {lipo }}$ & $5: 1$ & $171 \pm 41$ & 0.057 & $-29 \pm 3$ & 7 \\
\hline & Acetone & SQdFdC/SQMal $_{\text {lipo }}$ & $2: 1$ & $182 \pm 20$ & 0.047 & $-36 \pm 3$ & 3 \\
\hline \multirow[t]{3}{*}{$\mathbf{N 1} 1_{\mathrm{a}-\mathrm{P}}$} & Acetone & $\begin{array}{c}\text { SQdFdC/SQMal }_{\text {lipo }} / \\
\text { CKAAKN }\end{array}$ & $10: 1: 0.5$ & $281 \pm 10$ & 0.134 & $-15 \pm 1$ & $<3$ \\
\hline & Acetone & $\begin{array}{c}\text { SQdFdC/SQMal }_{\text {lipo }} / \\
\text { CKAAKN }\end{array}$ & $10: 1: 0.25$ & $187 \pm 7$ & 0.067 & $-11 \pm 1$ & $<3$ \\
\hline & Acetone & $\begin{array}{c}\text { SQdFdC/SQMal lipo/ }_{\text {lip }} \\
\text { CKAAKN }\end{array}$ & $5: 1: 0.5$ & Aggregation & / & / & l \\
\hline
\end{tabular}




\begin{tabular}{|c|c|c|c|c|c|c|c|}
\hline N1 $\mathbf{a}-\mathbf{P}^{*}$ & Acetone & $\begin{array}{c}\text { SQdFdC/SQMal }_{\text {lipo }} / \\
\text { CKAAKN }\end{array}$ & $5: 1: 0.25$ & $245 \pm 16$ & 0.141 & $-10 \pm 2$ & 3 \\
\hline \multirow[t]{3}{*}{ N1e } & Ethanol & $\mathrm{SQdFdC/SQMal}_{\text {lipo }}$ & $10: 1$ & $132 \pm 9$ & 0.100 & $-22 \pm 7$ & 3 \\
\hline & Ethanol & $\mathrm{SQdFdC/SQMal}_{\text {lipo }}$ & $5: 1$ & $167 \pm 9$ & 0.053 & $-22 \pm 3$ & 3 \\
\hline & Ethanol & $\mathrm{SQdFdC/SQMal}_{\text {lipo }}$ & $2: 1$ & Aggregation & I & I & I \\
\hline \multirow[t]{2}{*}{ N2a } & Acetone & SQdFdC/SQMal ${ }_{\text {hydro }}$ & $10: 1$ & Aggregation & I & I & I \\
\hline & Acetone & SQdFdC/SQMal $_{\text {hydro }}$ & $5: 1$ & Aggregation & I & I & 1 \\
\hline \multirow[t]{2}{*}{$\mathbf{N} 2 \mathrm{e}$} & Ethanol & SQdFdC/SQMal $_{\text {hydro }}$ & $10: 1$ & $183 \pm 5$ & 0.055 & $-16 \pm 1$ & $<3$ \\
\hline & Ethanol & SQdFdC/SQMal $_{\text {hydro }}$ & $5: 1$ & $177 \pm 3$ & 0.053 & $-25 \pm 3$ & $<3$ \\
\hline \multirow[t]{2}{*}{ N3 } & Acetone & $\begin{array}{c}\mathrm{SQMal}_{\text {lipo }} \\
0.5 \mathrm{mg} / \mathrm{mL}\end{array}$ & - & $600 \pm 180$ & 0.091 & $-56.57 \pm 3$ & 7 \\
\hline & Acetone & $\begin{array}{c}\text { SQMal }_{\text {lipo }} \\
1 \mathrm{mg} / \mathrm{mL}\end{array}$ & - & $387 \pm 101$ & 0.068 & $-38.47 \pm 3$ & 7 \\
\hline
\end{tabular}




\begin{tabular}{lcccccc}
\hline & Acetone & $\begin{array}{c}\text { SQMal lipo } \\
2 \mathrm{mg} / \mathrm{mL}\end{array}$ & - & $436 \pm 148$ & 0.099 & $-49.81 \pm 4$ \\
\hline N4-P & Ethanol & SQdFdC/SQCKAAKN & $1: 0.1$ & $186 \pm 104$ & 0.032 & $11 \pm 2$ \\
\hline & Ethanol & SQdFdC/SQCKAAKN & $1: 0.05$ & $897 \pm 11$ & 0.332 & $7 \pm 23$ \\
\hline N4-P* & Ethanol & SQdFdC/SQCKAAKN & $1: 0.01$ & $168 \pm 16$ & 0.117 & $-6 \pm 5$ \\
\hline
\end{tabular}

a NPs formulated using acetone as solvent

e NPs formulated using ethanol as solvent

* Formulations chosen for Surface Plasmon Resonance analysis and in vitro studies 
SQMal $_{\text {lipo }}$ alone was able to spontaneously self-assemble in water forming nanoparticles (N3) which, however, displayed a large mean diameter (400-600 nm) (Table 1).

Compared to SQdFdC NPs (No) or SQMal lipo NPs (N3), mixed SQdFdC/SQMal ${ }_{\text {lipo }}$ NPs showed an intermediate mean diameter with higher colloidal stability, suggesting that the conanoprecipitation technique allowed an efficient incorporation of SQMal ${ }_{\text {lipo }}$ in the resulting composite nanoparticles probably due to the capacity of the squalene chain to insert into the nanoparticle core. SQMal lipo NPs (N3) showed zeta potential values ranging from around -30 to $-60 \mathrm{mV}$. Accordingly, the zeta potential value of N1a (SQdFdC/SQMal ${ }_{\text {lipo }}$ NPs prepared using acetone) gradually decreased (from around -20 to $-40 \mathrm{mV}$ ) with the increase of SQMal ${ }_{\text {lipo }}$ in the formulation (Table 1). On the other hand, when ethanol was used as solvent (N1e), the amount of SQMal ${ }_{\text {lipo }}$ did not influence the zeta potential, suggesting that this experimental setting not only led to less stable NPs, but probably also did not allow the right exposition of the maleimide groups. Although for pure SQdFdC NPs the choice of the solvent did not influence the colloidal characteristics ${ }^{23,33-34}$, these results were in concordance with other experiments that highlighted the crucial role of the solvent in the nanoparticle selforganization $^{35-38}$; they also supported the choice of using only the acetone-formulated SQdFdC/SQMal ${ }_{\text {lipo }}$ NPs for further investigations.

\section{Preparation and characterization of targeted nanoparticles by coupling CKAAKN} peptide to preformed nanoparticles. As mentioned before, the CKAAKN peptide is able to react with the maleimide function of the spacer via the cysteine thiol group present in its sequence, leading to the formation of a stable thioether bond. Noteworthy is that this site of derivatization does not alter the ligand/receptor recognition, as confirmed by the fact that the same function was used for performing the previous phage display in vivo screening. ${ }^{29}$ 
CKAAKN conjugation on preformed nanoparticles allows peptide moieties to be disposed only at the surface of the carriers, thus being more available for the receptor recognition. For this purpose, the peptide thiol group was reacted with maleimide functions of $\mathbf{N 1}$ a (SQdFdC/SQMal ${ }_{\text {lipo }}$ molar ratio 10:1 or 5:1) using different Mal/peptide molar ratios (1:0.5 or 1:0.25) to obtain $\mathbf{N 1} \mathbf{a}-\mathbf{P}$. Targeted NPs showed a higher mean diameter compared to untargeted ones (Table 1). In some cases, aggregation occurred and/or the stability was very low. The zeta potential value increased with the peptide amount (from -23 to $-10 \mathrm{mV}$ ), probably due to the presence of two protonable amino groups in the CKAAKN moiety ((2) Figure 2).

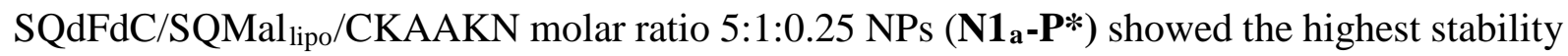
and only this nanoformulation was therefore used for further studies. The analyses of the amount of conjugated peptide on these NPs revealed the presence of 106866 peptide molecules per NP.

The interaction between the thiol groups and maleimide functions onto N1a surface was investigated by isothermal titration calorimetry (ITC) analysis. This technique is widely used in nanotechnology for characterizing thermodynamics and stoichiometry of intermolecular interactions allowing the evaluation of the association constant (K), the stoichiometry, the enthalpy $(\Delta \mathrm{H})$ and the entropy $(\Delta \mathrm{S})$ from which the Gibbs free energy $(\Delta \mathrm{G})$ of the process can be calculated. ${ }^{39-41}$ The heat flows were determined when peptide aliquots were added to N0a (used as control) or $\mathbf{N 1} \mathbf{a}$ suspension placed in the titration cell accurately thermostated (Figure 3a). ITC thermograms showed two different signatures: (i) a first one mainly related to the nonspecific adsorption of the peptide to the nanoparticle surface and (ii) a second one mostly attributed to the interaction with maleimide functions, observed only in the presence of these groups onto N1a. Such a hypothetical mechanism could be supported by the enthalpograms of the interaction between cysteine and maleimide groups in solution (Figure 3b). Whether the thiol-maleimide Michael addition happened on the nanoparticle surface (Figure 3b - blue line) 
or in solution (Figure 3b - black line), the thermodynamics parameters, including the stoichiometry of the interaction, were comparable. Despite the maleimide group was highly specific for thiols, at basic $\mathrm{pH}$ some secondary nucleophilic additions from the amine groups present in the two lysines of CKAAKN sequence could also take place, ${ }^{42-43}$ modifying the recognition sequence of the peptide. For this reason, we also verified that no interactions between lysines and the maleimide groups were established in the same conditions (Figure 3b - grey line). 
a)

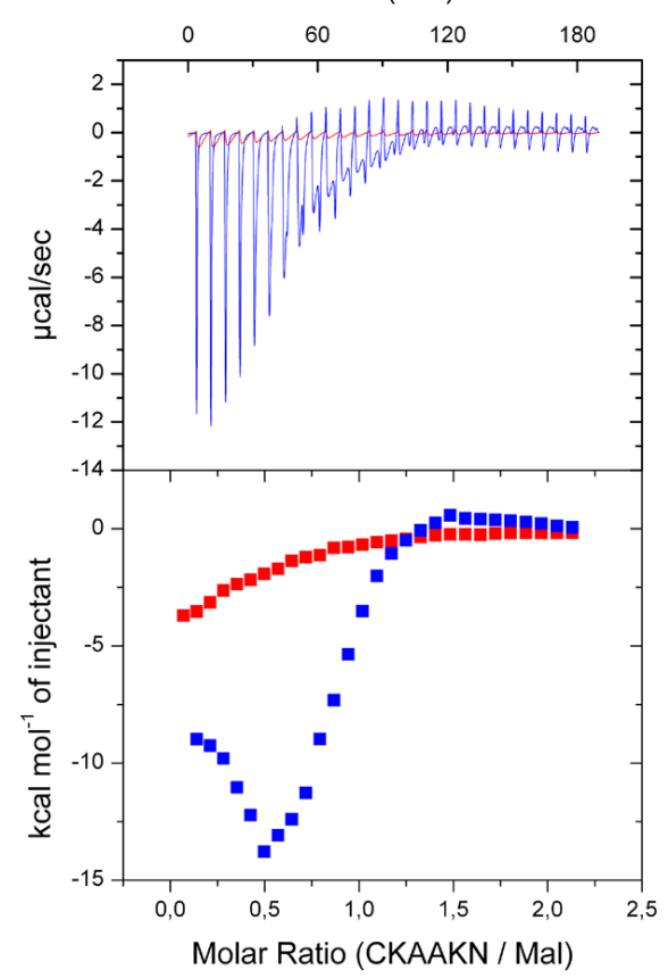

b)

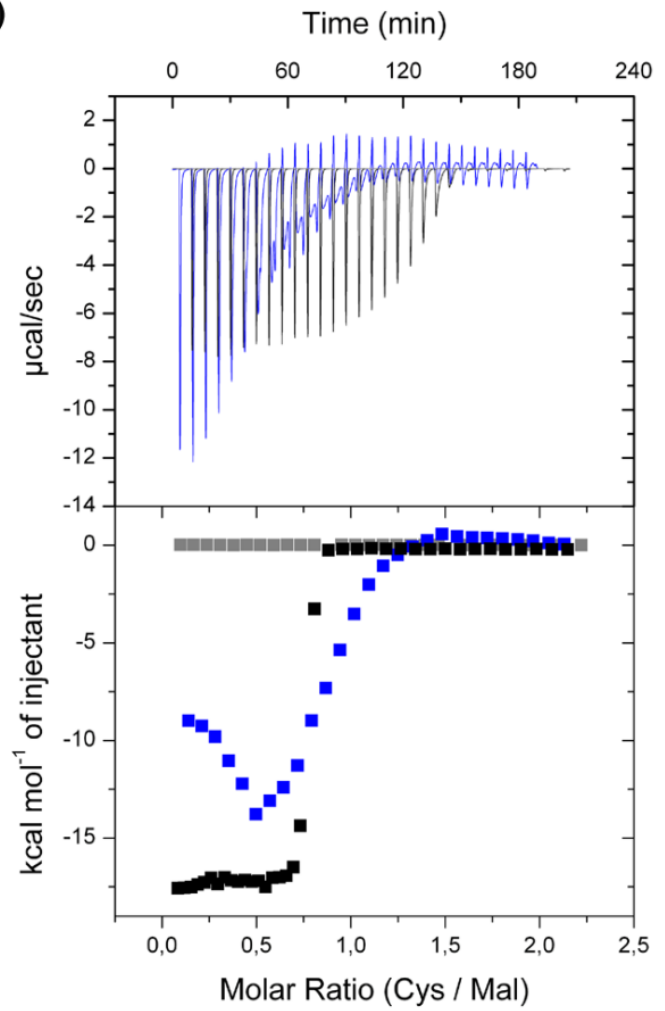

Figure 3. Isothermal titration calorimetry analysis of the interaction between CKAAKN, cysteine (Cys) and maleimide groups. The raw and the integrated binding heats are shown in the upper and lower panels, respectively. Heat flows accounting for dilution effects were further subtracted from each experimental heat flow. a) ITC thermograms upon injection of CKAAKN solution into either N0a (red) or N1a (blue) suspension. b) ITC thermograms upon injection of (i) a Cys solution into either maleimide solution (black) or N1a suspension (blue) and (ii) injection of lysine into maleimide solution (grey).

To be noted that, according to ITC results, the Michael addition reaction occurred in a larger extent for CKAAKN/Mal molar ratios $(\mathrm{N})$ higher than 0.5 . On the light of these results, it appeared that the CKAAKN/Mal molar ratio (1:0.25) used to formulate the $\mathbf{N 1} \mathbf{a}-\mathbf{P}^{*}$ led to the co-existence of both non-covalent interactions (demonstrated by ITC in other cases such as bio- 
molecular recognition or inclusion complexes ${ }^{39-41}$ ) and covalent conjugation of the CKAAKN onto the NP surface (Figure $1 \mathrm{~b}-v i$ ). However, higher CKAAKN/Mal molar ratios could not be used because they led to N1 a aggregation, (Table 1) likely due to peptide instability at the nanoparticle surface.

\section{Preparation of targeted nanoparticles by coupling CKAAKN to SQMal ${ }_{\text {lipo prior to }}$}

nanoparticle preparation. In this approach the CKAAKN peptide was previously conjugated to SQMal ${ }_{\text {lipo }}$ to give SQCKAAKN bioconjugate (5) which was then co-nanoprecipitated with SQdFdC at various SQdFdC/SQCKAAKN molar ratios (1:0.1, 1:0.05, 1:0.01), leading to the formation of peptide-functionalized NPs (N4-P). In this case only ethanol was used as organic solvent because of the limited solubility of SQCKAAKN in acetone. The main problem of this synthetic strategy is that the targeting agent could be buried in the nanoparticle core during the nanocarrier formation. Interestingly, the zeta potential gradually increased (from around -22 to $+11 \mathrm{mV}$ ) with the increase of the percentage of SQCKAAKN in the formulations, suggesting the surface distribution of the peptide. As observed by DLS analysis, a SQdFdC/SQCKAAKN molar ratio higher than 1:0.01 led to nanoparticle destabilization and aggregation. Hence, SQdFdC/SQCKAAKN 1:0.01 molar ratio NPs (N4-P*), which showed a significant decrease of the absolute surface charge compared to untargeted NPs (N0e) (-6 vs -22 mV) and only a slight increase of the mean diameter, were chosen for further investigations. According to the hydrophilic nature of the peptide we might assume that during the nanoprecipitation process the CKAAKN molecules localize on the NP surface. On the basis of the SQdFdC/SQCKAAKN 1:0.01 molar ratio used for N4-P* formulation, a value of 28385 molecules of CKAAKN per NP was obtained. Interestingly, N4-P* showed a marked reduction of the zeta potential value when increasing the $\mathrm{pH}$ of the medium from 7.4 to 9.8 (Figure 4). This probably resulted from the deprotonation of the lysine amino groups, thus supporting again the hypothesis of the 
presence of the peptide onto the surface of the nanoparticles, which is a crucial parameter to obtain an efficient targeting towards cancer cells. Only a slight increase of N4-P* mean diameter has been observed over a period of $72 \mathrm{~h}$ after incubation at $37^{\circ} \mathrm{C}$ in water and in cell culture medium containing 10\% FBS (SI Figure S4).

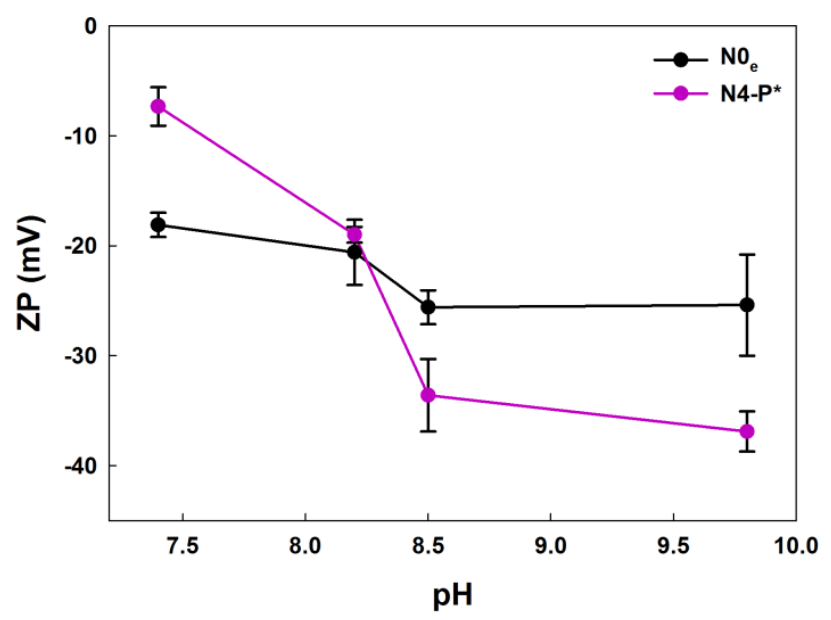

Figure 4. The surface charge of $\mathbf{N O}_{\mathbf{e}}$ and $\mathbf{N 4}-\mathbf{P}^{*}$ as a function of $\mathrm{pH}$ was investigated by zeta potential (ZP) measurement at $25^{\circ} \mathrm{C}$ after dilution with $0.02 \mathrm{M}$ phosphate buffer at $\mathrm{pH}$ values ranging from 7.4 to 9.8. Values represent mean $\pm \mathrm{SD}, n=3$.

Surface plasmon resonance analysis. While for $\mathbf{N 4 - P ^ { * }}$ the peptide was covalently conjugated to the nanoparticle surface, in the case of $\mathbf{N} \mathbf{1}_{\mathbf{a}}-\mathbf{P} *$ the ITC results suggested both adsorption and conjugation of the peptide on the NP surface. Covalent conjugation, in contrast to adsorption, ensures a stronger association between the ligand and the nanoparticles, especially after in vivo administration. ${ }^{44}$ However, ligand association to the nanoparticle by weak interactions or surface adsorption has also been proven as an alternative strategy to tailor targeted nanoparticles. ${ }^{44-45}$ Therefore, both coupling strategies were further investigated and the peptide targeting capability of $\mathbf{N 1} \mathbf{a}-\mathbf{P}^{*}$ and $\mathbf{N 4 - \mathbf { P } ^ { * }}$ was evaluated by surface plasmon resonance (SPR). Since it was reported that the sequence CKA-K shared motifs with the Wnt-2 protein ${ }^{29}$, 
sFRP-4, a secreted frizzled-related protein that binds Wnt-2, was immobilized onto the sensor chip surface. ${ }^{30,46}$ The ability of the free CKAAKN peptide to specifically interact with the sensor chip-immobilized sFRP-4 was also verified. ${ }^{30}$ Although both N1 a-P* and N4-P* were able to specifically interact with the receptor (which was not the case for untargeted N0e), N4P* enabled to reach the more important plasmonic signal after PBS washing (Figure 5). ${ }^{30}$

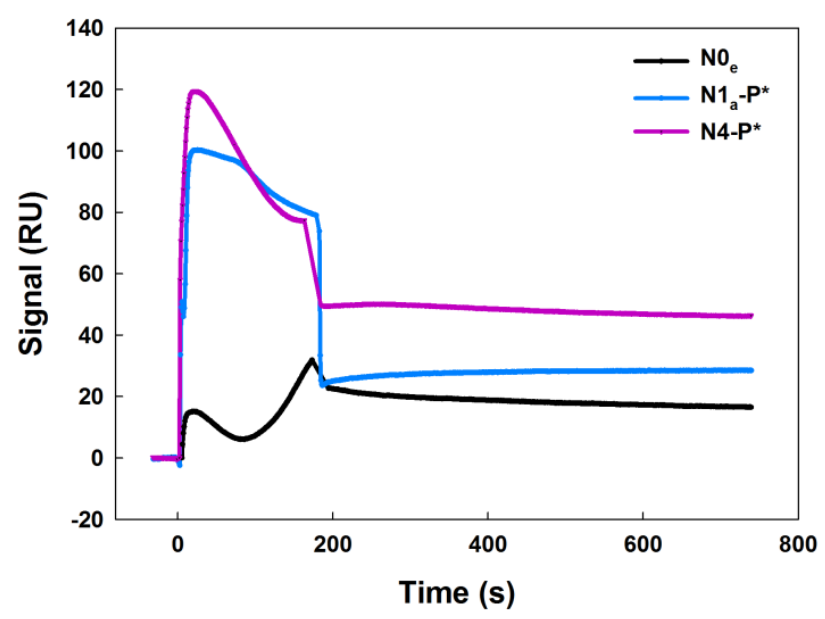

Figure 5. SPR sensorgrams (resonance units (RU) versus time) obtained by simultaneous injections of non functionalized SQdFdC NPs (N0e) $180 \mu \mathrm{M}$, SQdFdC/SQMal ${ }_{\text {lipo }} /$ CKAAKN 5:1:0.25 NPs (N1 $\left.\mathbf{a}-\mathbf{P}^{*}\right) 180 \mu \mathrm{M}$, SQdFdC/SQCKAAKN 1:0.01 NPs (N4-P*) $180 \mu \mathrm{M}$ over sFRP-4 immobilized on two parallel channels of the same sensor chip.

The enhanced target binding and specific avidity of N4-P* suggested that the peptide conjugation prior to nanocarrier formation was the most efficient methodology to obtain enhanced binding and avidity, ensuring stronger association between nanoparticles and sFRP4 receptor. This is of significance since earlier studies ${ }^{22,47-51}$ have shown that the binding of a surface-functionalized nanoparticle to its target receptor is not only relied to the presence of the ligand on the nanoparticle surface. 
In vitro studies. In order to confirm the on the bench SPR results, the receptor targeting ability as a function of the synthetic strategy was evaluated in in vitro cell culture experiments. To this purpose, a preliminary Western Blot analysis on several cell lines was performed in order to assess their frizzled-5(FZD-5) receptor expression (SI Figure S2). The MIA PaCa-2 cells were identified as high FZD-5-expressing cells and this result was further confirmed by immunocytochemistry (SI Figure S3). MIA PaCa-2 cells were then incubated for $6 \mathrm{~h}$ with BChol-green-labeled N0e, BChol-green-labeled N1a-P* or BChol-green-labeled N4-P*.

a)

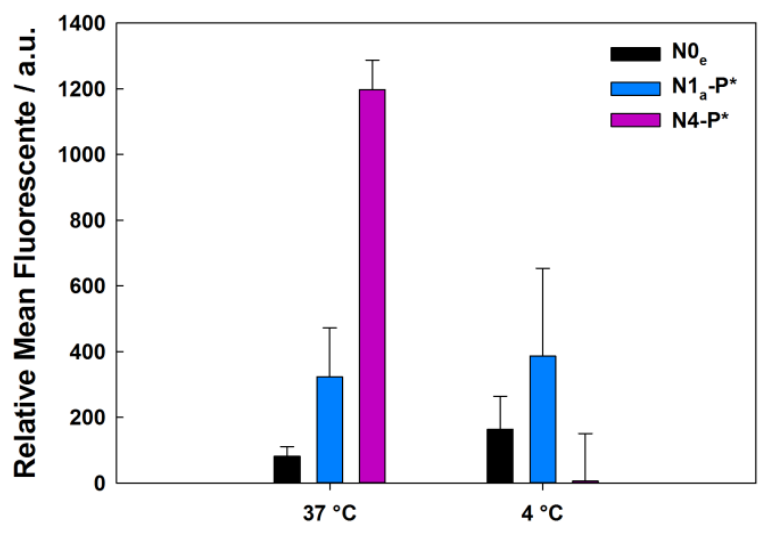

b)

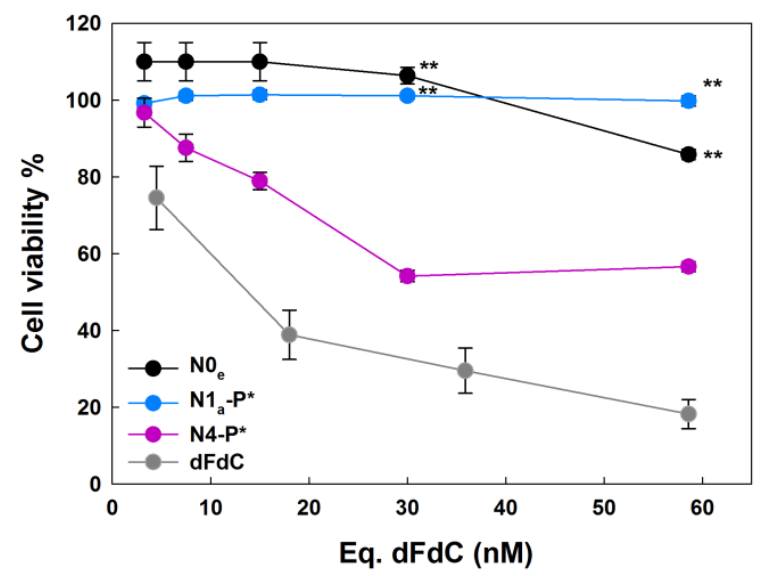

Figure 6. a) MIA PaCa-2 cell uptake quantification of SQdFdC NPs (N0e), 


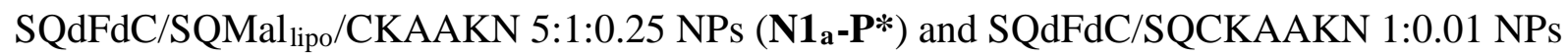
(N4-P*) after 6-h incubation at $37^{\circ} \mathrm{C}$ and $4{ }^{\circ} \mathrm{C}$. All NPs were labeled with BChol-green and incubated at a final concentration of $1 \mu \mathrm{M}$ eq. SQdFdC. b) Cell viability of MIA PaCa-2 cells treated with increasing concentrations of dFdC as free drug (dFdC), SQdFdC NPs (N0e), SQdFdC/SQMal ${ }_{\text {lipo }} /$ CKAAKN 5:1:0.25 NPs (N1a-P*) or SQdFdC/SQCKAAKN 1:0.01 NPs (N4-P*) for 72 h at $37^{\circ} \mathrm{C}$. Cytotoxicity of nanoparticles was compared to non-treated cells. Values represent mean \pm SEM. Statistical difference N0e vs N4-P* and N1a-P* vs N4-P* (Student's t-test with Bonferroni correction for multiple comparisons) is marked by $* *$ ( $\mathrm{p}<$ $0.01)$

Although slight differences were detected after treatment with $\mathbf{N 0}$ e and $\mathbf{N} \mathbf{1}_{\mathbf{a}}-\mathbf{P}^{*}$, remarkably the cell fluorescence intensity dramatically increased (by 14-fold) after N4-P* incubation (Figure 6a). These results clearly indicated a more efficient internalization of $\mathbf{N 4 - \mathbf { P } ^ { * }}$ in comparison to N1 $\mathbf{a}-\mathbf{P} *$ in MIA PaCa-2 cells.

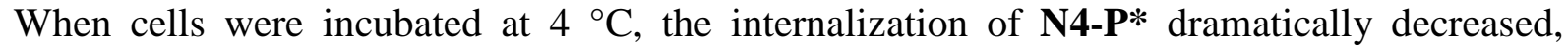
suggesting that peptide-functionalized NPs were internalized via an energy dependent route. The internalization of the nanocarrier is a key issue for the drug to be efficient. ${ }^{52}$ Thus, in order to investigate whether the peptide functionalization enabled to achieve an increased drug efficacy compared to the untargeted NPs, the in vitro cytotoxicity of the different NPs and the free drug was investigated. As previously reported ${ }^{25}$, all NPs were less cytotoxic than free dFdC due to their prodrug nature. Nevertheless, N4-P* caused a higher cytotoxicity compared to both $\mathbf{N 0}$ e and $\mathbf{N 1} \mathbf{a}_{\mathbf{a}} \mathbf{P}^{*}$ (Figure $6 \mathrm{~b}$ ). It is worth mentioning that for $\mathbf{N 4 - P *}$ the $50 \%$ inhibition of cell viability $\left(\mathrm{IC}_{50}\right)$ was already reached at $30 \mathrm{nM}$ (eq. $\mathrm{dFdC}$ ), while untargeted Noe were 
not efficient in killing cancer cells in these conditions. These results clearly demonstrated the ability of CKAAKN-functionalized NPs not only to keep the anticancer activity of the SQdFdC, but also to significantly enhance the cytotoxicity. As expected, according to the ITC, SPR and internalization data, $\mathbf{N} \mathbf{1}_{\mathbf{a}}-\mathbf{P}^{*}$ did not improve cytotoxicity in comparison to $\mathbf{N 0} \mathbf{e}$ treatment, thus suggesting the absence of specific tumor targeting ability when the peptide was mainly adsorbed at the NP surface.

To further investigate the ability of N4-P* to specifically target cancer cells, the interaction with NIH/3T3, a non cancerous fibroblastic cell line, was studied and compared to the uptake by MIA PaCa-2 cancer cells. Western blot analysis showed that NIH/3T3 healthy cells displayed a low expression of FZD-5 receptor (Supporting Information S2). As shown in Figure 7, non-functionalized nanoparticles (N0e) were taken-up mainly by NIH/3T3 fibroblasts in a nonspecific manner, resulting in higher accumulation in this cell line. On the contrary, N4-P* were internalized into MIA PaCa-2 cells by a receptor-mediated mechanism, which allowed nanoparticles achieving highly selective tumor cell uptake and toxicity, while decreasing nonspecific accumulation into healthy cells (Figure 7a). As shown by fluorescence quantification studies after $6 \mathrm{~h}$, the peptide-functionalization caused a 6-fold decrease of nanoparticles uptake by healthy NIH/3T3 cells compared to MIA Paca-2 cells (Figure 7b). Cytotoxicity studies clearly demonstrated that peptide functionalization was able to selectively increase cytoxicity toward MIA PaCa-2 pancreatic cancer cells. Indeed, the same concentration of N4-P* (i.e, 30 $\mathrm{nM}$ eq. $\mathrm{dFdC}$ ) responsible of the $50 \%$ reduction of cell viability on malignant MIA PaCa-2 cells maintained more than 93\% of viable healthy NIH/3T3 cells (Figure 7a). Of note, non functionalized NPs were not efficient in killing cancer cells, since 100\% cell viability was still observed after incubation at the same concentration. The higher uptake of N0e by NIH/3T3 fibroblasts was not accompanied by important cytotoxicity, as consequence of a lower sensitivity of this cell line to gemcitabine at the tested doses, as already reported in literature ${ }^{53-}$ 
54. The selective capture of functionalized NPs by cancer cells was further confirmed in a coculture experiment of healthy NIH/3T3 cells (stained in green) and MIA PaCa-2 cells (unstained) incubated with red fluorescently-labeled nanoparticles (Figure 7c,d). Confocal images clearly showed similar uptake of non-functionalized NPs in both tumor and healthy cells (Figure 7c), whereas N4-P* were selectively captured by tumor cells and healthy cells were saved from nanoparticles recognition (Figure 7d).

a)
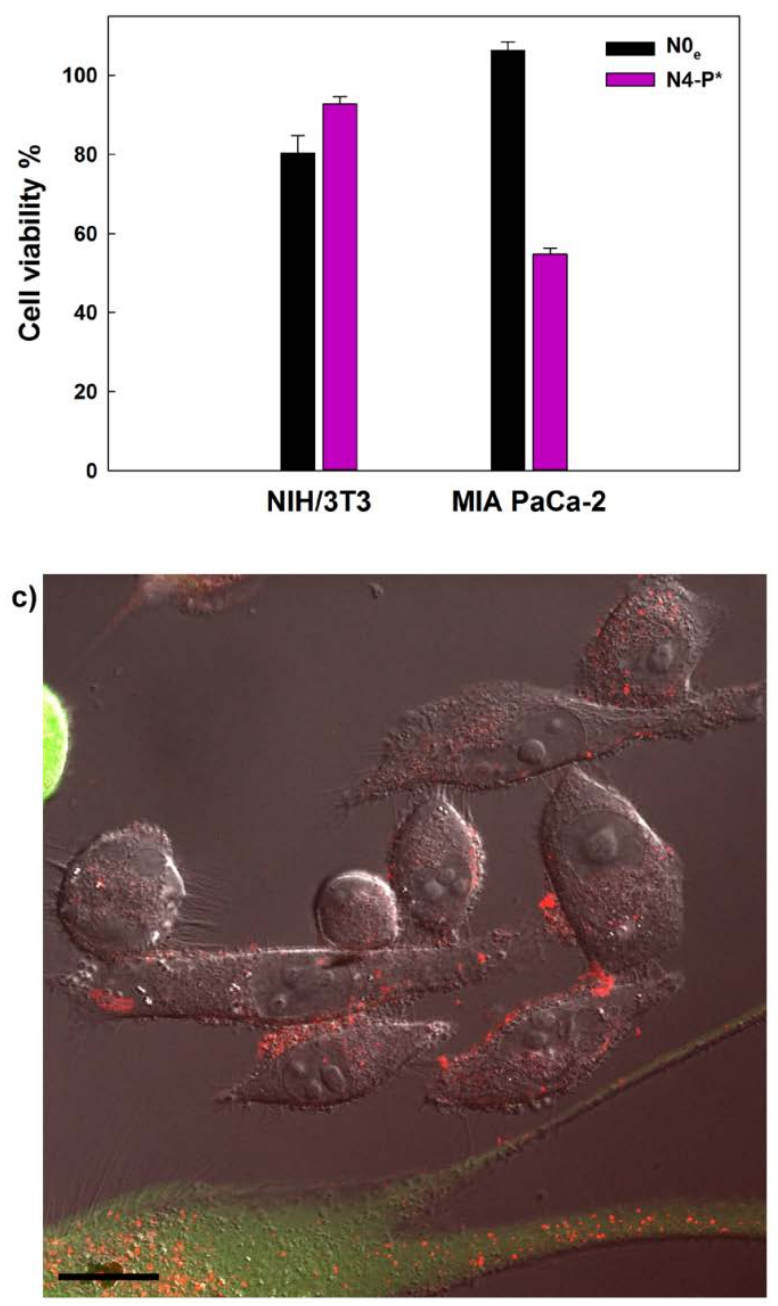

b)
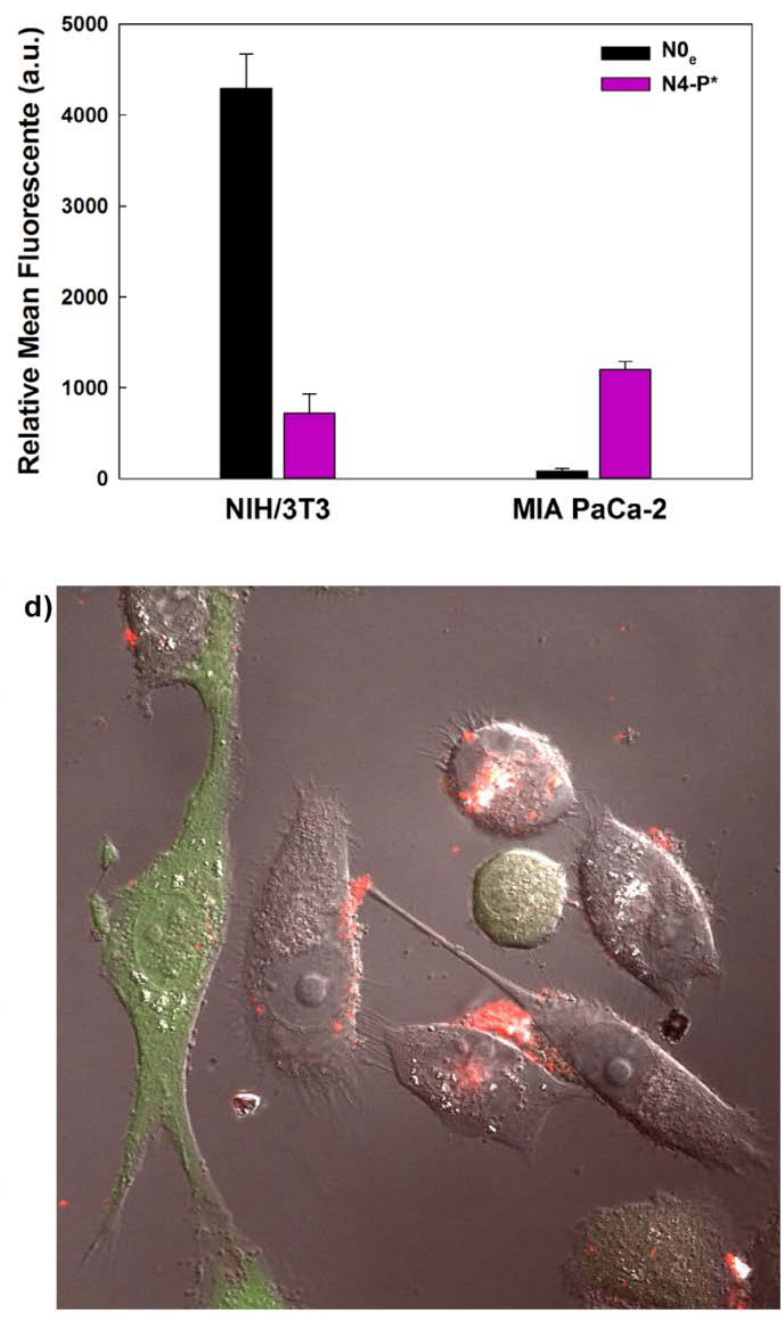

Figure 7. (a) Viability of NIH/3T3 and MIA Paca-2 cells treated for 72 h with SQdFdC NPs (N0e) and SQdFdC/SQCKAAKN NPs (N4-P*) (30 nM eq. dFdC). Values represent mean \pm 
SEM. (b) Quantification of cellular uptake of BChol-green-labeled SQdFdC NPs (N0e) and BChol-green-labeled SQdFdC/SQCKAAKN NPs (N4-P*) in NIH/3T3 and MIA PaCa-2 cells at $37^{\circ} \mathrm{C}$. Values represent mean \pm SEM. (c) Confocal laser-scanning microscopy images of a coculture of NIH/3T3 (green) and MIA PaCa-2 cells (unstained) after incubation with BCholred-labeled SQdFdC NPs (Noe) and (d) BChol-red-labeled SQdFdC/SQCKAAKN NPs (N4$\left.\mathbf{P}^{*}\right)$. Scale bar $=20 \mu \mathrm{m}$. 


\section{CONCLUSIONS}

This study demonstrates that the best strategy to prepare CKAAKN-functionalized SQdFdC NPs relies in the conjugation of the peptide to the SQMal ${ }_{\text {lipo }}$ derivative prior nanoparticle formation. Taken together, our results clearly highlight that actively targeted nanoparticles should not be simply designed as single modular assemblies of scaffold, linker and targeting ligand, but rigorous studies must be performed in order to clarify how different structural components collaborate to reach the most efficient cell targeting ability. In a nutshell, the successful functionalization of SQdFdC nanoparticles makes this system a good example to highlight the subtle equilibrium which governs the design of actively targeted NPs able to effectively improve anticancer activity.

\section{EXPERIMENTAL PROCEDURES}

Chemicals. Gemcitabine (2',2'-difluorodeoxycitidine, dFdC) hydrochloride was purchased from Sequoia Research Products Ltd. (Pangbourne, UK). CKAAKN peptide was purchased from CASLO Laboratory Aps (Lyngby, Denmark). Squalene, dextrose, maleimide and all other reagents were obtained by Sigma-Aldrich Chemical Co. (Milan, Italy). Squalene derivatives (Figure 2) (4-(N)-trisnorsqualenoylgemcitabine $\quad(\mathrm{SQdFdC}) \quad(\mathbf{1})^{23}, \quad 6-$ (maleimidocaproyl)hydrazone of squalene $\left(\mathrm{SQMal}_{l i p o}\right)(3)^{30}$, 2-[2-(2,5-dioxo-2,5-dihydro-1Hpyrrol-1-yl)ethoxy]ethyl （4E,8E,12E,16E)-4,8,13,17,21-pentamethyl-docosa-4,8,12,16,20-

pentaenoate (SQMal ${ }_{\text {hydro }}$ ) $(\mathbf{4})^{31}$ ) were obtained as previously reported. All solvents were of analytical grade from Carlo Erba Reagenti (Milan, Italy) or VWR (Fontenay-sous-Bois, France).

Preparation and characterization of non targeted nanoparticles. SQdFdC, SQdFdC/SQMal ${ }_{\text {lipo }}$, SQdFdC/SQMal ${ }_{\text {hydro }}$ and SQMal ${ }_{\text {lipo }}$ nanoparticles (NPs) were prepared by nanoprecipitation. ${ }^{23,55}$ (Table 1) Practically, for SQdFdC NPs (N0), 2 mg of SQdFdC were 
dissolved in acetone (N0a) or ethanol (N0e); the organic solution was then added dropwise under magnetic stirring into $\mathrm{MilliQ}^{\circledR}$ water (solvent/water 1:2 v/v). Formation of the nanoparticles occurred spontaneously without using any surfactant. After solvent evaporation under reduced pressure, an aqueous suspension of nanoparticles was obtained (final SQdFdC concentration: $2 \mathrm{mg} / \mathrm{mL})$.

For SQdFdC/SQMal ${ }_{\text {lipo }}$ NPs (N1), SQdFdC and SQMal lipo were co-dissolved in acetone (N1 a) or ethanol (N1e) in various SQdFdC/SQMal ${ }_{\text {lipo }}$ molar ratios (10:1 (2 mg of SQdFdC and 0.183 mg of SQMal ${ }_{\text {lipo }}$ ), 5:1 (2 mg of SQdFdC and 0.366 mg of SQMal ${ }_{\text {lipo }}$ ) and 2:1 (2 mg of SQdFdC and $0.915 \mathrm{mg}$ of $\mathrm{SQMal}_{\text {lipo }}$ )). The organic solution was then added dropwise under magnetic stirring into MilliQ ${ }^{\circledR}$ water (solvent/water 1:2 v/v). Formation of the nanoparticles occurred spontaneously without using any surfactant. After solvent evaporation under reduced pressure, an aqueous suspension of nanoparticles was obtained (final SQdFdC concentration: $2 \mathrm{mg} / \mathrm{mL}$ ). For SQdFdC/SQMal ${ }_{\text {hydro NPs (N2), SQdFdC and SQMal }}$ hydro were co-dissolved in ethanol in various molar ratios (10:1 (2 mg of SQdFdC and 0.164 mg of SQMal ${ }_{\text {hydro }}$ ) and 5:1 (2 mg of SQdFdC and $0.328 \mathrm{mg}$ of SQMal $\left.{ }_{\text {hydro }}\right)$ ). The organic solution was then added dropwise under magnetic stirring into MilliQ ${ }^{\circledR}$ water (ethanol/water 1:2 v/v). Formation of the nanoparticles occurred spontaneously without using any surfactant. After solvent evaporation under reduced pressure, an aqueous suspension of nanoparticles was obtained (final SQdFdC concentration: 2 $\mathrm{mg} / \mathrm{mL})$.

For SQMal ${ }_{\text {lipo }}$ NPs (N3), 2 mg of SQMal lipo were dissolved in acetone at various concentrations. After the addition of the organic solution to MilliQ ${ }^{\circledR}$ water (acetone/water 1:2 v/v) and solvent evaporation, an aqueous suspension of nanoparticles was obtained (SQMal ${ }_{\text {lipo }}$ concentration: $0.5,1$ or $2 \mathrm{mg} / \mathrm{mL})$.

Fluorescently-labeled SQdFdC NPs and fluorescently-labeled SQdFdC/SQMal ${ }_{\text {lipo }}$ NPs were obtained using the same procedure, unless $1 \%(\mathrm{w} / \mathrm{w})$ of the fluorescent probe CholEsteryl 
BODIPY ${ }^{\circledR}$ FL C12 (BChol-green) or CholEsteryl BODIPY ${ }^{\circledR}$ 542/563 C11 (Life Technologies, Molecular Probes, Saint Aubin, France) was dissolved in the ethanolic solution before dropwise addition into water.

The mean particle size and the polydispersity index of all formulations were measured by dynamic light scattering (DLS) with a Nano ZS from Malvern (UK) (173 scattering angle) at $25^{\circ} \mathrm{C}$. The measurements were performed after dilution of the NP suspensions $(1 / 25 \mathrm{v} / \mathrm{v})$ in MilliQ ${ }^{\circledR}$ water. The NP surface charge was investigated by zeta potential measurements at 25 ${ }^{\circ} \mathrm{C}$ after dilution with $0.05 \mathrm{mM} \mathrm{KCl}$ solution applying the Smoluchowski equation and using the same apparatus. Measurements were carried out in triplicate. The colloidal stability of the formulations was evaluated by measuring the size and the zeta potential of the nanoparticles over a storage period of 7 days at $4{ }^{\circ} \mathrm{C}$.

\section{Preparation and characterization of targeted nanoparticles by coupling CKAAKN} peptide to preformed nanoparticles. CKAAKN stock solution (100X) was prepared by dissolving the peptide in $1 \mathrm{mM}$ freshly degased phosphate buffer at $\mathrm{pH}$ 8.2. To obtain CKAAKN-conjugated SQdFdC/SQMal lipo NPs (N1-P), $100 \mu \mathrm{L}$ of N1a were added dropwise under gentle magnetic stirring to $1 \mathrm{~mL}$ of CKAAKN working solution (1X) in various molar ratios $\left(\mathrm{SQdFdC/SQMal}{ }_{\text {lipo }} / \mathrm{CKAAKN}\right.$ molar ratio 10:1:0.5 (0.2 mg of SQdFdC, $0.0183 \mathrm{mg}$ of $\mathrm{SQMal}_{\text {lipo }}$ and $0.0098 \mathrm{mg}$ of CKAAKN) or 10:1:0.25 (0.2 mg of SQdFdC, $0.0183 \mathrm{mg}$ of $\mathrm{SQMal}_{\text {lipo }}$ and $0.0049 \mathrm{mg}$ of CKAAKN) or 5:1:0.5 (0.2 mg of SQdFdC, $0.036 \mathrm{mg}$ of SQMal ${ }_{\text {lipo }}$ and $0.0196 \mathrm{mg}$ of CKAAKN) or 5:1:0.25 (0.2 mg of SQdFdC, $0.036 \mathrm{mg}$ of SQMal lipo $_{\text {and }}$ $0.0098 \mathrm{mg}$ of CKAAKN); final SQdFdC concentration: $0.18 \mathrm{mg} / \mathrm{mL}$ ) (Table 1). The reaction was carried out for $1 \mathrm{~h}$ at room temperature under stirring. The CKAAKN-functionalized nanoparticles (N1 $\mathbf{a}-\mathbf{P})$ were then purified from unreacted peptide by centrifugal filter units (30 $\mathrm{kDa}$ ) at $14000 \mathrm{~g}$ for 1 minute (Amicon Ultra-0.5, Millipore). The mean size, the polydispersity index and the zeta potential of purified $\mathbf{N 1} \mathbf{a}-\mathbf{P}$ were determined at $25{ }^{\circ} \mathrm{C}$ by DLS as described 
above. The stability of the formulations was evaluated by measuring the size and the zeta potential of the nanoparticles over a storage period of 7 days at $4{ }^{\circ} \mathrm{C}$. The amount of peptide molecules at the surface of the NPs has been evaluated by: $i$ ) titration of unreacted peptide in an unpurified aliquot of conjugated nanoassemblies by reaction with the Ellman's reagent (5,5'dithio-bis-(2-nitrobenzoic acid), DTNB) by quantitative UV spectrophotometric analysis (absorbance at $412 \mathrm{~nm})^{56}$; ii) a retro-titration of the available maleimide groups present on the nanoparticle surface by quantitative fluorimetric analysis (Maleimide Quantification Assay Kit (Fluorometric) Abcam, ab112141) according to manufacturer’s instructions.

Isothermal titration calorimetry (ITC) analysis of $\mathbf{N 1}$ a nanoparticles. The interaction between the maleimide (Mal) function and the CKAAKN peptide was investigated by isothermal titration calorimetry. The ITC instrument (VP-ITC, MicroCal, GE Healthcare Life Sciences, Velizy-Villacoublay, France) was periodically calibrated either electrically, using an internal electric heater, or chemically by measuring the dilution enthalpy of methanol in water. This standard reaction was in excellent agreement (1-2\%) with the MicroCal constructor data. ${ }^{57-58}$ In a typical experiment, aliquots of $10 \mu \mathrm{L}$ of CKAAKN peptide, cysteine (Cys) or lysine in 0.03 M phosphate buffer solution at pH 8.2 (3.1 mM eq. Cys or $12.4 \mathrm{mM}$ eq. lysine) filled into $283 \mu \mathrm{L}$ syringe were used to titrate a suspension of either $\mathrm{N} 1_{\mathrm{a}}$ or maleimide in $0.03 \mathrm{M}$ phosphate buffer solution at $\mathrm{pH} 8.2$ (0.31 mM eq. Mal) into the calorimetric cell accurately thermostated at $25^{\circ} \mathrm{C}$. The corresponding heat flows were recorded as a function of time. Intervals between injections were $600 \mathrm{~s}$ and agitation speed was $220 \mathrm{rpm}$. Control experiments with Noa into the calorimetric cell were carried out using the equivalent total squalene amount present in N1a. Background of titration consisted on injecting the CKAAKN peptide or Cys in solely phosphate buffer solution placed in the sample cell.

The interaction process was analyzed by employing the models proposed in the Windows-based Origin 7 software package supplied by MicroCal. Based on the concentrations of the two 
species, the software used a nonlinear least-squares algorithm to fit the series of heat flows to an equilibrium binding equation, providing the best-fit values of the stoichiometry, binding constant $(\mathrm{K})$ and change in enthalpy $(\Delta \mathrm{H})$. From these results, the differences in free energy $(\Delta \mathrm{G})$ and the entropy $(\Delta \mathrm{S})$ were deducted according to the equation:

$\Delta \mathrm{G}=-\mathrm{RT} \ln \mathrm{K}=\Delta \mathrm{H}-\mathrm{T} \Delta \mathrm{S}$

Preparation of targeted nanoparticles by coupling CKAAKN to SQMal lipo prior to nanoparticle preparation. To obtain SQdFdC/SQCKAAKN nanoparticles (N4-P), CKAAKN peptide was first conjugated to SQMal ${ }_{\text {lipo }}$ to give SQCKAAKN (5) (SI Figure S1). To obtain SQMal $_{\text {lipo }}$ (3), a solution of 1,1',2-trisnorsqualenic aldehyde (8) (0.334 g, $\left.0.868 \mathrm{mmol}\right)$ in $\mathrm{CH}_{2} \mathrm{Cl}_{2}$ was added to dry methanol $(15 \mathrm{~mL})$. The resulting mixture was sonicated few minutes until complete dissolution. [6-(maleimido)hexanamido]azanium trifluoroacetate (7) (0.306 g, $0.868 \mathrm{mmol}$ ) and $4 \AA$ molecular sieves (200 mg) were then added and the reaction mixture was stirred for $1 \mathrm{~h}$ at room temperature under nitrogen. The formation of the desired product (3) was monitored by TLC (petroleum ether/ethyl acetate $1 / 1 \mathrm{v} / \mathrm{v}, \mathrm{R}_{\mathrm{f}}: 0.65$ ). The mixture was filtered and concentrated under reduced pressure. The residue was taken into water (5 mL) and extracted with $\mathrm{CH}_{2} \mathrm{Cl}_{2}$ (3 x $15 \mathrm{~mL}$ ). The combined organic phases were dried over anhydrous $\mathrm{MgSO}_{4}$ and concentrated in vacuo. Purification by flash-chromatography on silica column, eluting with a gradient of petroleum ether to petroleum ether/ethyl acetate 60/40 v/v, gave the product as a light yellow waxy material (0.211 g, 63\% yield) (SI Figure S1).

${ }^{1} \mathrm{H} \mathrm{NMR}\left(\mathrm{CDCl}_{3}\right) \delta: 8.39(\mathrm{~s}, 1 \mathrm{H}, \mathrm{CH}=\mathrm{NN}), 7.05$ (t, $\left.J=5.2 \mathrm{~Hz}, 1 \mathrm{H}, \mathrm{NHCO}\right), 6.68$ (s, 2H, CO$\mathrm{CH}=\mathrm{CHCO}), 5.14-5.07\left(\mathrm{~m}, 5 \mathrm{H}, \mathrm{HC}=\mathrm{C}\left(\mathrm{CH}_{3}\right)\right), 3.54-3.49\left(\mathrm{t}, J=7.2 \mathrm{~Hz}, 2 \mathrm{H}, \mathrm{CH}_{2} \mathrm{~N}\right), 2.70-2.50$ (m, 2H, $\left.\mathrm{CH}_{2} \mathrm{CONH}\right), 2.40-1.90\left(\mathrm{~m}, 2 \mathrm{H},=\mathrm{C}\left(\mathrm{CH}_{3}\right) \mathrm{CH}_{2} \mathrm{CH}_{2}\right), 1.80\left(\mathrm{~s}, 3 \mathrm{H}, \mathrm{HC}=\mathrm{C}\left(\mathrm{CH}_{3}\right)_{2}\right), 1.76-$ $1.65\left(\mathrm{~m}, 12 \mathrm{H}, \mathrm{HC}=\mathrm{C}\left(\mathrm{CH}_{3}\right) \mathrm{CH}_{2}\right), 1.62-1.60\left(\mathrm{~m}, 4 \mathrm{H}, \mathrm{NCH}_{2} \mathrm{CH}_{2} \mathrm{CH}_{2} \mathrm{CH}_{2} \mathrm{CH}_{2} \mathrm{CON}\right), 1.41-1.33$ (m, $\left.2 \mathrm{H}, \mathrm{NCH}_{2} \mathrm{CH}_{2} \mathrm{CH}_{2} \mathrm{CH}_{2} \mathrm{CH}_{2} \mathrm{CON}\right) .{ }^{13} \mathrm{C} \mathrm{NMR}\left(\mathrm{CDCl}_{3}\right) \delta: 171.2,166.3,147.3,135.8,135.7-$ 132.0, 125.9-124.7, 42.5, 39.7-26.4, 38.2, 36.6, 31.0, 26.9, 25.9, 24.6-16.4, 22.4. MS (EI): 
m/z(\%) 81 (70), 110 (100), 192 (55), 591 (3). HPLC analysis: Symmetry C18 column, $5 \mu \mathrm{m}$ (Merck, Italy) equipped with a C18 column guard, elution with 100\% methanol, detection by UV adsorption measurement at $237 \mathrm{~nm}$ (flow rate $1 \mathrm{~mL} / \mathrm{min}, \mathrm{t}_{\mathrm{r}}=5.79 \mathrm{~min}$ ). Peak heights were recorded and processed on a CBM-10A Shimadzu interface.

To synthesize the Michael adduct of CKAAKN (2) and 6-(maleimidyl)-hexanoic acid (trisnorsqualenylidene)-hydrazide (3) (SQCKAAKN, (5)), a mixture of SQMal ${ }_{\text {lipo }}$ (3) (13.5 mg, $0.0229 \mathrm{mmol}$ ) and CKAAKN peptide (2) (7.25 mg, $0.0114 \mathrm{mmol})$ in dimethylformamide $(\mathrm{DMF}) / \mathrm{H}_{2} \mathrm{O} 3 / 1 \mathrm{v} / \mathrm{v}(2 \mathrm{~mL})$ was stirred for $3 \mathrm{~h}$ at $40{ }^{\circ} \mathrm{C}$. The reaction mixture was then concentrated under reduced pressure and the crude product was taken into diethyl ether to remove unreacted maleimide derivative. The supernatant was withdrawn after decantation (3 times). In order to eliminate unreacted peptide, the solid was dissolved in methanol and filtered through a sintered glass funnel. The product was obtained as a translucent waxy material (10 mg, $0.0082 \mathrm{mmol}, 70 \%$ yield). ${ }^{30}$ (SI Figure S1).

${ }^{1} \mathrm{H}$ NMR $\left(\mathrm{CD}_{3} \mathrm{OD}, 400 \mathrm{MHz}\right)$ due to the presence of a 7:3 E/Z mixture at the hydrazone bond and to the asymmetric center on the maleimide moiety some signals are split, $\delta: 7.43(\mathrm{t}, J=5.4$ $\mathrm{Hz}, 0.7 \mathrm{H}, \mathrm{CH}=\mathrm{NNHCO}), 7.28$ (m, 0.3H, $\mathrm{CH}=\mathrm{NNHCO}), 5.20$ (t, $\left.J=6.6 \mathrm{~Hz}, 1 \mathrm{H}, \mathrm{HC}=\mathrm{C}\left(\mathrm{CH}_{3}\right)\right)$, 5.15-5.06 (m, 4H, $\left.\mathrm{HC}=\mathrm{C}\left(\mathrm{CH}_{3}\right)\right), 4.71\left(\mathrm{t}, J=5.6 \mathrm{~Hz}, 1 \mathrm{H}, \mathrm{NOCCH}\left(\mathrm{CH}_{2} \mathrm{CONH}_{2}\right) \mathrm{NH}\right), 4.42-4.25$ (m, 5H, NOCCH(CH 3$) \mathrm{NH}, \quad \mathrm{NOCCH}\left(\mathrm{CH}_{2} \mathrm{CH}_{2} \mathrm{CH}_{2} \mathrm{CH}_{2} \mathrm{NH}_{3}\right) \mathrm{NH}, \mathrm{NOCCH}\left(\mathrm{CH}_{2} \mathrm{~S}\right) \mathrm{NH}_{2}$,), 3.70-3.60 (m, 1H, $\mathrm{CH}_{2} \mathrm{~S}\left(\mathrm{CHCH}_{2} \mathrm{CONCO}\right), 3.52$ (t, $J=7.0 \mathrm{~Hz}, 2 \mathrm{H}, \mathrm{CH}_{2} \mathrm{~N}$-maleimide), 3.50$3.43\left(\mathrm{~m}, \quad 1 \mathrm{H}, \quad \mathrm{CH}_{2} \mathrm{SCHCH} \mathrm{CH}_{2} \mathrm{CO}, \quad 3.30-3.10 \quad\left(\mathrm{~m}, \quad 3 \mathrm{H}, \quad \mathrm{CH}_{2} \mathrm{~S}\left(\mathrm{CHCH}_{2} \mathrm{CONCO}\right)\right.\right.$, $\mathrm{CH}_{2} \mathrm{~S}\left(\mathrm{CHCH}_{2} \mathrm{CONCO}\right), 3.02-2.92$ (m, 4H, $\mathrm{CH}_{2} \mathrm{CH}_{2} \mathrm{CH}_{2} \mathrm{CH}_{2} \mathrm{NH}_{3}$ ), 2.83 (dd, $J=16.0 \mathrm{~Hz}, J=$ $\left.6.4 \mathrm{~Hz}, 1 \mathrm{H}, \mathrm{NOCCH}\left(\mathrm{CH}_{2} \mathrm{CONH}_{2}\right) \mathrm{NH}\right), 2.76(\mathrm{dd}, J=16.0 \mathrm{~Hz}, J=4.8 \mathrm{~Hz}, 1 \mathrm{H}$, $\left.\mathrm{NOCCH}\left(\mathrm{CH}_{2} \mathrm{CONH}_{2}\right) \mathrm{NH}\right), 2.62-2.30\left(\mathrm{~m}, 4 \mathrm{H}, \mathrm{CH}_{2} \mathrm{CH}_{2} \mathrm{CON}, \mathrm{CH}_{2} \mathrm{CH}_{2} \mathrm{C}=\mathrm{NNH}\right), \quad 2.25-2.15$ $\left(\mathrm{m}, \quad 4 \mathrm{H}, \quad \mathrm{CH}_{2} \mathrm{CH}_{2} \mathrm{NH}_{3}\right), \quad 2.17-1.85 \quad\left(\mathrm{~m}, \quad 22 \mathrm{H}, \quad=\mathrm{C}\left(\mathrm{CH}_{3}\right) \mathrm{CH}_{2} \mathrm{CH}_{2}\right.$, $\left.\operatorname{NOCCH}\left(\mathrm{CH}_{2} \mathrm{CH}_{2} \mathrm{CH}_{2} \mathrm{CH}_{2} \mathrm{NH}_{3}\right) \mathrm{NH}\right), \quad 1.75-1.65 \quad$ (m, 
$\left.\operatorname{NOCCH}\left(\mathrm{CH}_{2} \mathrm{CH}_{2} \mathrm{CH}_{2} \mathrm{CH}_{2} \mathrm{NH}_{3}\right) \mathrm{NH}\right), \quad 1.67 \quad\left(\mathrm{~s}, \quad 3 \mathrm{H}, \quad=\mathrm{C}\left(\mathrm{CH}_{3}\right)_{2}\right), \quad 1.64 \quad(\mathrm{~s}, \quad 3 \mathrm{H}$, $\left.=\mathrm{C}\left(\mathrm{CH}_{3}\right) \mathrm{CH}_{2} \mathrm{CH}_{2}\right), \quad 1.60 \quad\left(\mathrm{~s}, \quad 12 \mathrm{H}, \quad=\mathrm{C}\left(\mathrm{CH}_{3}\right) \mathrm{CH}_{2} \mathrm{CH}_{2}\right), \quad 1.60-1.45 \quad(\mathrm{~m}, \quad 4 \mathrm{H}$, $=\mathrm{NHNCOCH}_{2} \mathrm{CH}_{2} \mathrm{CH}_{2} \mathrm{CH}_{2} \mathrm{CH}_{2} \mathrm{~N}$-maleimide), 1.40 (d, $\left.J=7.2 \mathrm{~Hz}, 6 \mathrm{H}, \mathrm{COCH}\left(\mathrm{CH}_{3}\right) \mathrm{NH}\right)$, $\mathrm{HNCOCH}_{2} \mathrm{CH}_{2} \mathrm{CH}_{2} \mathrm{CH}_{2} \mathrm{CH}_{2} \mathrm{~N}$-maleimide); MS (+ESI), m/z (\%), 1226.0 (100) [M+H] $]^{+}, 614.5$ (3) $[\mathrm{M}+2 \mathrm{H}]^{2+}$; HRMS (+ESI) calcd for $\mathrm{C}_{62} \mathrm{H}_{105} \mathrm{~N}_{12} \mathrm{O}_{5} \mathrm{~S}$ : 1225.7741; found 1225.7690 .

Nanoparticles were then prepared by nanoprecipitation. Practically, SQdFdC and SQCKAAKN were dissolved in $0.1 \mathrm{~mL}$ of ethanol in various molar ratios (SQdFdC/SQCKAAKN 1:0.1 (3.42 mg of SQdFdC and $0.64 \mathrm{mg}$ of SQCKAAKN), 1:0.05 (3.42 mg of SQdFdC and $0.32 \mathrm{mg}$ of SQCKAAKN) and 1:0.01 (3.42 mg of SQdFdC and 0.064 mg of SQCKAAKN)) and this organic solution was then added dropwise under magnetic stirring into $1 \mathrm{~mL}$ of MilliQ ${ }^{\circledR}$ water (ethanol/water 0.1:1 v/v). After solvent evaporation under reduced pressure, an aqueous suspension of nanoparticles (N4-P) was obtained (final SQdFdC concentration: $3.4 \mathrm{mg} / \mathrm{mL}$ ) (Table 1). The mean size and the polydispersity index of the formulations were determined as described above. The NP surface charge was investigated by zeta potential measurements at 25 ${ }^{\circ} \mathrm{C}$ after dilution with $0.05 \mathrm{mM} \mathrm{KCl}$ solution or $0.02 \mathrm{M}$ phosphate buffer at $\mathrm{pH}$ values ranging from 7.4 to 9.8, applying the Smoluchowski equation and using the same apparatus. Fluorescently-labeled nanoparticles were prepared as described above. The stability of N4-P* has been investigated over a period of $72 \mathrm{~h}$ after incubation at $37^{\circ} \mathrm{C}$ in water and in cell culture medium containing 10\% FBS.

Surface plasmon resonance (SPR) analysis. Interaction analyses were performed on a BIAcore T100 instrument using CM5 Series S sensor chip from GE Healthcare Life Sciences Europe. The activation of the carboxymethylated dextran matrix was performed with a mixture of $\quad 0.1 \mathrm{M} \quad \mathrm{N}$-ethyl- $N^{\prime}$-(3-diethylaminopropyl)-carbodiimide $\quad$ (EDC) $/ 20.4 \mathrm{M} \quad N$ hydroxysuccinimide (NHS) (1:1 v/v) (GE Healthcare) for 7 min. Running buffer for the immobilization process was $150 \mathrm{mM}$ phosphate buffer, $\mathrm{pH} 7.4$ at a flow rate of $10 \mu \mathrm{L} / \mathrm{min}$. The 
sFRP-4 receptor was then injected over the activated surface at $10 \mu \mathrm{g} / \mathrm{mL}$ in $10 \mathrm{mM}$ sodium acetate buffer at pH 4.4 during $7 \mathrm{~min}$, giving an average immobilization level of 2800 resonance units (RU). A solution of $1 \mathrm{M}$ ethanolamine hydrochloride at $\mathrm{pH} 8.5$ was then injected during 7 min to block the unreacted sites of the matrix. For reference, an additional blank flow channel was prepared in accordance with the same process without injecting the receptor over the surface. Binding capacities of the functional surfaces were tested with 180 s-injections of a peptide solution, N0e, N1a-P* (SQdFdC/SQMal/CKAAKN molar ratio 5:1:0.25) or N4-P* (SQdFdC/SQCKAAKN molar ratio 1:0.01) at different concentrations. All experiments were carried out in duplicate at $25{ }^{\circ} \mathrm{C}$ in Dulbecco-PBS (D-PBS) running buffer on the InterMolIPSIT platform (Châtenay-Malabry, France).

Cell culture. Human pancreatic carcinoma cell lines MIA PaCa-2, BxPC3, PANC-1, breast cancer cell line MCF-7 and embryonic murine fibroblasts NIH/3T3 were obtained from the American Type Culture Collection (Molsheim, France) and maintained as recommended. Briefly, MIA PaCa-2, PANC-1, MCF-7 and NIH/3T3 cells were grown in Dulbecco's Modified Eagle Medium (DMEM) supplemented with $10 \%$ heat-inactivated $\left(56^{\circ} \mathrm{C}, 30 \mathrm{~min}\right)$ fetal bovine serum (FBS). In addition, MIA Paca-2 cell medium was supplemented with $2.5 \%$ heatinactivated horse serum (Gibco, Saint Aubin, France). BxPC3 cells were maintained in Roswell Park Memorial Institute medium (RPMI 1640 Lonza, Braine-l’Alleud, Belgium) supplemented with $10 \%$ heat-inactivated FBS. All media were further supplemented with $50 \mathrm{U} \cdot \mathrm{mL}^{-1}$ penicillin and 50 U.mL ${ }^{-1}$ streptomycin (Lonza, Levallois, France). Cells were maintained in a humid atmosphere at $37^{\circ} \mathrm{C}$ with $5 \% \mathrm{CO}_{2}$. Cells were used between passage 3 and 12 after thawing.

Western Blot. Pancreatic adenocarcinoma (BxPC3, MIA PaCa-2, PANC-1), breast cancer (MCF-7) and embryonic fibroblast cells (NIH/3T3) were lysed in RIPA buffer (SigmaAldrich) supplemented with Pierce ${ }^{\mathrm{TM}}$ phosphatase and protease inhibitor cocktail (Thermo Fisher Scientific, Perbio Science, Brebières, France), vortexed and then centrifuged for 5 min 
at $3000 \mathrm{~g}$. The protein concentration in the supernatant was then measured using a colorimetric assay (Bio-Rad Protein Assay Dye, Bio-Rad Laboratories, Marnes-la-Coquette, France). Equal amount of proteins $(30 \mu \mathrm{g})$ were boiled for $10 \mathrm{~min}$ with the same volume of Laemmli Sample Buffer (Bio-Rad Laboratories, Marnes-la-Coquette, France), supplemented with 5\% betamercaptoethanol and then separated in sodium dodecylsulphate (SDS)-polyacrylamide gels (Mini-Protean - TGX 4-15\% - Precast Gels Bio-Rad) and electrically transferred to polyvinylidene difluoride (PVDF) membrane using a semi-dry transfer system (20 V, $1 \mathrm{~h})$. The membrane was blocked with 5\% dry milk suspension in 0.1\% Tween 20 in PBS (blocking buffer), then incubated for $2 \mathrm{~h}$ at room temperature with the primary antibody solution in blocking buffer and, after 30 min washing in PBS-Tween $200.1 \%$ buffer, incubated for $1 \mathrm{~h}$ at room temperature with the secondary antibody solution in blocking buffer. Antibodies were used at the following dilutions: polyclonal rabbit anti-FZD-5 diluted 1/1000 (Millipore), mouse anti- $\beta$-actin diluted 1/3000 (Sigma-Aldrich), goat anti-mouse secondary antibody conjugated to horse radish-peroxydase diluted 1/2000 (SantaCruz Biotechnology, Clinisciences, Nanterre, France) and goat anti-rabbit secondary antibody conjugated to horse radish-peroxydase diluted 1/5000 (SantaCruz Biotechnology, Clinisciences). Detection of chemiluminescence was performed using the Clarity ${ }^{\mathrm{TM}}$ Western ECL substrate (Bio-Rad Laboratories) and images were captured by the ChemiBIS system from DNR Bioimaging Systems (Thoiry, France). MCF-7 cell line was used as a positive control. ${ }^{59}$

Immunocytochemistry. MIA PaCa-2 cells $\left(2.5 \times 10^{4}\right.$ cells/mL) were plated in growing medium onto microscopic glass slides in 24-well plate and incubated for $24 \mathrm{~h}$ at $37^{\circ} \mathrm{C}$ with $5 \%$ $\mathrm{CO}_{2}$. Nuclei were stained with $10 \mu \mathrm{M}$ Syto Red Fluorescent dye (SYTO61 - S11343, Life Technologies, Molecular Probes, Saint Aubin, France) according to the manufacturer's protocol. After staining, cells were fixed with 4\% paraformaldehyde in PBS, incubated for 30 min at room temperature in blocking solution (1\% bovine serum albumin, $0.3 \mathrm{M}$ glycine, $0.1 \%$ 
Tween 20 in PBS) and then with the polyclonal rabbit anti-FZD-5 diluted 1/500 (Abcam, UK) for $1 \mathrm{~h}$. Then, the cells were washed with PBS-Tween $200.1 \%$ for $30 \mathrm{~min}$ and stained for $1 \mathrm{~h}$ at room temperature in dark with an Alexa Fuor ${ }^{\circledR} 555$-conjugated secondary antibody diluted 1/500 (Abcam, UK). Cells were then rinsed three times with PBS and analyzed by confocal laser scanning microscopy. Cells incubated with the Alexa Fuor ${ }^{\circledR} 555$-conjugated secondary antibody diluted 1/500 only were used as negative control.

Cell internalization of NPs. MIA PaCa-2 or NIH/3T3 cells (5 x $10^{4}$ cells/mL) were cultured in 12-well plates for $24 \mathrm{~h}$ to achieve approximately $40 \%$ confluence. Cells were then incubated at $37{ }^{\circ} \mathrm{C}$ with $5 \% \mathrm{CO}_{2}$ for $6 \mathrm{~h}$ with $1 \mu \mathrm{M}$ of freshly prepared BChol-green-labeled SQdFdC NPs $\quad$ (No $),_{\text {e }} \quad$ SQdFdC/SQMal ${ }_{\text {lipo }} /$ CKAAKN $\quad 5: 1: 0.25 \quad$ NPs $\quad($ N1a-P*) SQdFdC/SQCKAAKN 1:0.01 NPs (N4-P*). Free BChol-green was used as control. After treatment, supernatants were discarded, cells rinsed twice with PBS and harvested for measurement. Cell suspensions were analyzed by flow cytometry (Accuri C6, BD Biosciences, Le Pont de Claix, France) and mean fluorescence intensities were collected between 515 and $545 \mathrm{~nm}$, using the 488-nm line of an argon laser for excitation. For all experiments 10000 cells were measured from each sample.

For low temperature experiments, the cells were incubated in the cold room at $4{ }^{\circ} \mathrm{C}$ for $5 \mathrm{~h}$. Results were expressed as the ratio of the mean fluorescence intensity of each sample to the mean fluorescence intensity of non treated cells. This value was then corrected by the fluorescence factor of each NP suspension. All measurements were performed in triplicate or more to determine means and SD.

Cytotoxicity studies. The in vitro cytotoxicity of NPs was investigated on MIA PaCA2 and NIH/3T3 cell lines through the determination of the mitochondrial activity, using the 3(4,5-dimethylthiazol-2-yl)-2,5-diphenyl tetrazolium bromide test (MTT, Sigma-Aldrich). Briefly, cells were seeded in $100 \mu \mathrm{L}$ of growth medium (MIA PaCa-2 ( 1 x $10^{4}$ cells/mL), 
NIH/3T3 $\left(0.75 \times 10^{4}\right.$ cells/mL $\left.)\right)$ in 96-well plates and preincubated for $24 \mathrm{~h}$. Cells were then treated with $100 \mu \mathrm{L}$ of a series of concentrations of different nanoparticle suspensions for $72 \mathrm{~h}$. Initial cell density and incubation time were determined to allow cells to remain in exponential growth and to undergo two cell-doubling times during the assay. At the end of the incubation period, $20 \mu \mathrm{L}$ of a $5 \mathrm{mg} / \mathrm{mL}$ MTT solution in phosphate buffered saline were added to each well. After $2 \mathrm{~h}$ of incubation, the culture medium was removed and replaced by $200 \mu \mathrm{L}$ of dimethyl sulfoxide (DMSO), in order to dissolve the formazan crystals. The absorbance of the solubilized dye was measured spectrophotometrically with a microplate reader (LAB System Original Multiscan MS) at $570 \mathrm{~nm}$. The percentage of viable cells for each treatment was calculated from the ratio of the absorbance of the well containing the treated cells versus the average absorbance of the control wells (i.e., untreated cells). All experiments were set up in triplicate.

Coculture. NIH/3T3 fibroblasts $\left(7.5 \times 10^{4}\right.$ cells $)$ were plated onto microscopic glass slides and incubated for $18 \mathrm{~h}$ at $37{ }^{\circ} \mathrm{C}$ with $5 \% \mathrm{CO}_{2}$ in complete medium. To visualize and distinguish between NIH/3T3 fibroblasts and MIA PaCa-2 cells in coculture, NIH/3T3 cells were stained with $5 \mu \mathrm{M}$ CellTracker green 5-chloromethylfluorescein diacetate (CMFDA, Life Technology, Molecular Probes) according to the manufacturer's protocol. After staining, cells were left to rest for 2 h at $37^{\circ} \mathrm{C}$ with $5 \% \mathrm{CO}_{2}$ in cell culture medium, and then unstained MIA PaCa-2 cells (15 x $10^{4}$ cells) were co-incubated. The seeding ratio between MIA PaCa-2 and NIH/3T3 cells was 2:1 due to the faster doubling time of the latter. After $18 \mathrm{~h}$, the coculture was incubated with BChol-red-labeled SQdFdC NPs and BChol-red-labeled SQdFdC/SQCKAAKN NPs diluted in fresh cell culture medium at $10 \mu \mathrm{M}$. At different time points $(2,6$, and $24 \mathrm{~h})$ nanoparticles were withdrawn and cells washed with pre-warmed culture medium before imaging. Free BChol-red was used as control. 
Confocal laser scanning microscopy. Observations were made by sequential acquisition with a Zeiss LSM-510 confocal laser microscope equipped with a $1 \mathrm{~mW}$ argon laser and $1 \mathrm{~mW}$ helium neon laser, using a Plan-Apochromat 20X or 63X objective lens (NA 1.40, oil immersion). Green fluorescence (CMFDA) was observed with a band-pass 505 and $550 \mathrm{~nm}$ emission filter and under a $488 \mathrm{~nm}$ laser illumination. Red fluorescence (BChol-red) was observed with a long-pass $560 \mathrm{~nm}$ emission filter and under a $543 \mathrm{~nm}$ laser illumination. The pinhole diameter was set at $98 \mu \mathrm{m}$ for CMFDA and $106 \mu \mathrm{m}$ for BChol-red and an optical section thickness of $0.4 \mu \mathrm{m}$ was fixed. Twelve bit numerical images were acquired with Carlo Zeiss ZEN 2011 software version 7.1.

\section{ACKNOWLEDGEMENTS}

The authors warmly thank Dr. Christine Vauthier, Dr. Gilles Ponchel, Dr. Julien Nicolas, Dr. Nicolas Tsapis, Miss Giovanna Giacalone (CNRS UMR 8612, Institut Galien Paris-Sud) and Dr. Emeric Gueneau (GE Healthcare, Life Sciences) for helpful discussion in ITC and SPR analysis. This work was supported by MIUR - University of Turin "Fondi Ricerca Locale (ex60\%)” and by the European Research Council under the European Community's Seventh Framework Program FP7/2007-2013 Grant Agreement N²49835. The authors acknowledge the Università Italo Francese/Université Franco Italienne for supporting the $\mathrm{PhD}$ co-tutoring of S.V. The CNRS and the French Ministry of Research are also warmly acknowledged for financial support.

\section{SUPPORTING INFORMATION AVAILABLE}

\section{Supporting Information}


Synthesis of SQCKAAKN, western blot analysis, immunocytochemistry analysis and stability studies are provided. This information is available free of charge via the Internet at http://pubs.acs.org.

\section{AUTHOR INFORMATION}

\section{Corresponding author}

* E-mail: barbara.stella@unito.it. Tel.: +39 0116706800. Fax: +39 0116706663

\section{Notes}

The authors declare no competing financial interest.

\section{ABBREVIATIONS}

dFdC, Gemcitabine; DLS, Dynamic light scattering; DMEM, Dulbecco's modified eagle medium; EDC, $N$-ethyl- $N$ '-(3-diethylaminopropyl)-carbodiimide; ESI, electron spray ionization; FBS, Fetal bovine serum; FZD, Frizzled; IC50, half maximal inhibitory concentration; ITC, Isothermal titration calorimetry; MTT, 3-(4,5-dimethylthiazol-2-yl)-2,5diphenyltetrazoliumbromide; NP, Nanoparticle; NHS, $\mathrm{N}$-hydroxysuccinimide; $\mathrm{NO}_{\mathrm{a}}$, SQdFdC nanoparticles, acetone as organic solvent; $\mathrm{N} 0$ e, SQdFdC nanoparticles, ethanol as organic solvent; N1, SQdFdC/SQMal lipo nanoparticles; $\mathrm{N1}_{\mathrm{a}}$, SQdFdC/SQMal lipo $_{\text {nanoparticles, acetone }}$ as organic solvent; $\mathrm{N} 1_{\mathrm{e}}, \mathrm{SQdFdC/SQMal}$ lipo nanoparticles, ethanol as organic solvent; N2, SQdFdC/SQMal ${ }_{\text {hydro }} \quad$ nanoparticles; N3, SQMal lipo nanoparticles; N4-P, SQdFdC/SQCKAAKN nanoparticles; PDI, Polydispersity index; SD, standard deviation; SEM, standard error of the mean; SPR, Surface plasmon resonance; SQ, Squalene; SQdFdC, 4-(N)1,1',2-Trisnorsqualenoylgemcitabine/4-( $N)$-1,1',2-trisnorsqualenoyl-2',2'-difluoro-2'deoxycytidine; SQdFdC/SQCKAAKN NPs, CKAAKN-functionalized squalenoylgemcitabine nanoparticles; SQCKAAKN, Michael adduct of CKAAKN and 6-(2,5-dioxo-2,5-dihydro-1H- 
pyrrol-1-yl)-N'-[(4E,8E,12E,16E)-4,8,13,17,21-pentamethyldocosa-4,8,12,16,20-pentaen-1ylidene]hexanehydrazide; $\quad$ SQMal ${ }_{h y d r o}, \quad$ 2-[2-(2,5-Dioxo-2,5-dihydro-1H-pyrrol-1yl)ethoxy]ethyl (4E,8E,12E,16E)-4,8,13,17,21-pentamethyldocosa-4,8,12,16,20-pentaenoate; SQMal $_{\text {lipo, }}$ 6-(2,5-Dioxo-2,5-dihydro-1H-pyrrol-1-yl)-N'-[(4E,8E,12E,16E)-4,8,13,17,21pentamethyldocosa-4,8,12,16,20-pentaen-1-ylidene]hexanehydrazide; ZP, Zeta potential. 


\section{REFERENCES}

(1) Hanahan, D., and Weinberg, R. A. (2011) Hallmarks of cancer: the next generation. Cell 144, 646-674.

(2) Krause, D. S., and Van Etten, R. A. (2005) Tyrosine kinases as targets for cancer therapy. N. Engl. J. Med. 353, 172-187.

(3) Collins, I., and Workman, P. (2006) New approaches to molecular cancer therapeutics. Nat. Chem. Biol. 2, 689-700.

(4) Chari, R. V. (2008) Targeted cancer therapy: conferring specificity to cytotoxic drugs. Acc. Chem. Res. 41, 98-107.

(5) Dosio, F., Brusa, P., and Cattel, L. (2011) Immunotoxins and anticancer drug conjugate assemblies: the role of the linkage between components. Toxins (Basel) 3, 848-883.

(6) Flygare, J. A., Pillow, T. H., and Aristoff, P. (2013) Antibody-drug conjugates for the treatment of cancer. Chem. Biol. Drug Des. 81, 113-121.

(7) http://www.fda.gov/NewsEvents/Newsroom/PressAnnouncements/ucm268781.htm.

(8) http://www.medscape.com/viewarticle/779751.

(9) Wang, M., and Thanou, M. (2010) Targeting nanoparticles to cancer. Pharmacol. Res. 62, 90-99.

(10) Montet, X., Funovics, M., Montet-Abou, K., Weissleder, R., and Josephson, L. (2006) Multivalent effects of RGD peptides obtained by nanoparticle display. J. Med. Chem. 49, 6087-6093.

(11) Nicolas, J., Mura, S., Brambilla, D., Mackiewicz, N., and Couvreur, P. (2013) Design, functionalization strategies and biomedical applications of targeted biodegradable/biocompatible polymer-based nanocarriers for drug delivery. Chem. Soc. Rev. 42, 1147-1235. 
(12) Valetti, S., Mura, S., Stella, B., and Couvreur, P. (2013) Rational design for multifunctional non-liposomal lipid-based nanocarriers for cancer management: theory to practice. J. Nanobiotechnology 11, S6.

(13) Peer, D., Karp, J. M., Hong, S., Farokhzad, O. C., Margalit, R., and Langer, R. (2007) Nanocarriers as an emerging platform for cancer therapy. Nat. Nanotechnol. 2, 751-760.

(14) Davis, M. E., Chen, Z. G., and Shin, D. M. (2008) Nanoparticle therapeutics: an emerging treatment modality for cancer. Nat. Rev. Drug Discov. 7, 771-782.

(15) Cheng, Z., Al Zaki, A., Hui, J. Z., Muzykantov, V. R., and Tsourkas, A. (2012) Multifunctional nanoparticles: cost versus benefit of adding targeting and imaging capabilities. Science 338, 903-910.

(16) Lammers, T., Kiessling, F., Hennink, W. E., and Storm, G. (2012) Drug targeting to tumors: principles, pitfalls and (pre-) clinical progress. J. Control. Release 161, 175187.

(17) Bae, Y., Nishiyama, N., and Kataoka, K. (2007) In vivo antitumor activity of the folateconjugated pH-sensitive polymeric micelle selectively releasing adriamycin in the intracellular acidic compartments. Bioconjug. Chem. 18, 1131-1139.

(18) Canovi, M., Markoutsa, E., Lazar, A. N., Pampalakis, G., Clemente, C., Re, F., Sesana, S., Masserini, M., Salmona, M., Duyckaerts, C., Flores, O., Gobbi, M., and Antimisiaris, S. G. (2011) The binding affinity of anti-Abeta1-42 MAb-decorated nanoliposomes to Abeta1-42 peptides in vitro and to amyloid deposits in post-mortem tissue. Biomaterials 32, 5489-5497.

(19) Fakhari, A., Baoum, A., Siahaan, T. J., Le, K. B., and Berkland, C. (2011) Controlling ligand surface density optimizes nanoparticle binding to ICAM-1. J. Pharm. Sci. 100, 1045-1056. 
(20) Huwyler, J., Wu, D., and Pardridge, W. M. (1996) Brain drug delivery of small molecules using immunoliposomes. Proc. Natl. Acad. Sci. U. S. A. 93, 14164-14169.

(21) Le Droumaguet, B., Souguir, H., Brambilla, D., Verpillot, R., Nicolas, J., Taverna, M., Couvreur, P., and Andrieux, K. (2011) Selegiline-functionalized, PEGylated poly(alkyl cyanoacrylate) nanoparticles: Investigation of interaction with amyloid-beta peptide and surface reorganization. Int. J. Pharm.416, 453-460.

(22) Tassa, C., Duffner, J. L., Lewis, T. A., Weissleder, R., Schreiber, S. L., Koehler, A. N., and Shaw, S. Y. (2010) Binding affinity and kinetic analysis of targeted small moleculemodified nanoparticles. Bioconjug. Chem. 21, 14-19.

(23) Couvreur, P., Stella, B., Reddy, L. H., Hillaireau, H., Dubernet, C., Desmaele, D., Lepetre-Mouelhi, S., Rocco, F., Dereuddre-Bosquet, N., Clayette, P., Rosilio, V., Marsaud, V., Renoir, J. M., and Cattel, L. (2006) Squalenoyl nanomedicines as potential therapeutics. Nano Lett. 6, 2544-2548.

(24) Oberstein, P. E., and Saif, M. W. (2011) First-line treatment for advanced pancreatic cancer. Highlights from the "2011 ASCO Gastrointestinal Cancers Symposium". San Francisco, CA, USA. January 20-22, 2011. JOP 12, 96-100.

(25) Reddy, L. H., Renoir, J. M., Marsaud, V., Lepetre-Mouelhi, S., Desmaele, D., and Couvreur, P. (2009) Anticancer efficacy of squalenoyl gemcitabine nanomedicine on 60 human tumor cell panel and on experimental tumor. Mol. Pharm. 6, 1526-1535.

(26) Reddy, L. H., Ferreira, H., Dubernet, C., Mouelhi, S. L., Desmaele, D., Rousseau, B., and Couvreur, P. (2008) Squalenoyl nanomedicine of gemcitabine is more potent after oral administration in leukemia-bearing rats: study of mechanisms. Anticancer Drugs 19, 999-1006. 
(27) Rejiba, S., Reddy, L. H., Bigand, C., Parmentier, C., Couvreur, P., and Hajri, A. (2011) Squalenoyl gemcitabine nanomedicine overcomes the low efficacy of gemcitabine therapy in pancreatic cancer. Nanomedicine 7, 841-849.

(28) Hidalgo, M. (2010) Pancreatic cancer. N. Engl. J. Med. 362, 1605-1617.

(29) Joyce, J. A., Laakkonen, P., Bernasconi, M., Bergers, G., Ruoslahti, E., and Hanahan, D. (2003) Stage-specific vascular markers revealed by phage display in a mouse model of pancreatic islet tumorigenesis. Cancer Cell. 4, 393-403.

(30) Valetti, S., Maione, F., Mura, S., Stella, B., Desmaele, D., Noiray, M., Vergnaud, J., Vauthier, C., Cattel, L., Giraudo, E., and Couvreur, P. (2014) Peptide-functionalized nanoparticles for selective targeting of pancreatic tumor. J. Control. Release 192C, 2939.

(31) Raouane, M., Desmaele, D., Gilbert-Sirieix, M., Gueutin, C., Zouhiri, F., Bourgaux, C., Lepeltier, E., Gref, R., Ben Salah, R., Clayman, G., Massaad-Massade, L., and Couvreur, P. (2011) Synthesis, characterization, and in vivo delivery of siRNAsqualene nanoparticles targeting fusion oncogene in papillary thyroid carcinoma. $J$. Med. Chem. 54, 4067-4076.

(32) Bekkara-Aounallah, F., Gref, R., Othman, M., Reddy, L. H., Pili, B., Allain, V., Bourgaux, C., Hillaireau, H., Lepêtre-Mouelhi, S., Desmaële, D., Nicolas, J., Chafi, N., and Couvreur, P. (2008) Novel PEGylated Nanoassemblies Made of Self-Assembled Squalenoyl Nucleoside Analogues. Adv. Funct. Mat. 18, 3715-3725.

(33) Desmaele, D., Gref, R., and Couvreur, P. (2012) Squalenoylation: a generic platform for nanoparticular drug delivery. J. Control. Release 161, 609-618.

(34) Lepeltier, E., Bourgaux, C., Rosilio, V., Poupaert, J. H., Meneau, F., Zouhiri, F., Lepetre-Mouelhi, S., Desmaele, D., and Couvreur, P. (2013) Self-assembly of squalene- 
based nucleolipids: relating the chemical structure of the bioconjugates to the architecture of the nanoparticles. Langmuir 29, 14795-14803.

(35) Bouchemal, K., Briancon, S., Perrier, E., and Fessi, H. (2004) Nano-emulsion formulation using spontaneous emulsification: solvent, oil and surfactant optimisation. Int. J.Pharm.280, 241-251.

(36) Ganachaud, F., and Katz, J. L. (2005) Nanoparticles and nanocapsules created using the Ouzo effect: Spontaneous emulsification as an alternative to ultrasonic and high-shear devices. Chemphyschem 6, 209-216.

(37) Legrand, P., Lesieur, S., Bochot, A., Gref, R., Raatjes, W., Barratt, G., and Vauthier, C. (2007) Influence of polymer behaviour in organic solution on the production of polylactide nanoparticles by nanoprecipitation. Int. J. Pharm. 344, 33-43.

(38) Yu, W., Doegito, E. S. T., Barratt, G., Fessi, H., Devissaguet, J. P., and Puisieux, F. (1993) A Novel-Approach to the Preparation of Injectable Emulsions by a Spontaneous Emulsification Process. Int. J. Pharm. 89, 139-146.

(39) Agostoni, V., Chalati, T., Horcajada, P., Willaime, H., Anand, R., Semiramoth, N., Baati, T., Hall, S., Maurin, G., Chacun, H., Bouchemal, K., Martineau, C., Taulelle, F., Couvreur, P., Rogez-Kreuz, C., Clayette, P., Monti, S., Serre, C., and Gref, R. (2013) Towards an Improved anti-HIV Activity of NRTI via Metal-Organic Frameworks Nanoparticles. Adv. Healthc. Mater. 2, 1630-1637.

(40) Bouchemal, K. (2008) New challenges for pharmaceutical formulations and drug delivery systems characterization using isothermal titration calorimetry. Drug Discov. Today 13, 960-972.

(41) Mazzaferro, S., Bouchemal, K., Gallard, J. F., Iorga, B. I., Cheron, M., Gueutin, C., Steinmesse, C., and Ponchel, G. (2011) Bivalent sequential binding of docetaxel to methyl-beta-cyclodextrin. Int. J. Pharm. 416, 171-180. 
(42) Hermanson, G. T. (1996) Bioconjugate Techniques. First, Academic Press, San Diego.

(43) Furgeson, D. Y., Dreher, M. R., and Chilkoti, A. (2006) Structural optimization of a "smart" doxorubicin-polypeptide conjugate for thermally targeted delivery to solid tumors. J. Control. Release 110, 362-369.

(44) Avvakumova, S., Colombo, M., Tortora, P., and Prosperi, D. (2014) Biotechnological approaches toward nanoparticle biofunctionalization. Trends Biotechnol. 32, 11-20.

(45) Occhipinti, E., Verderio, P., Natalello, A., Galbiati, E., Colombo, M., Mazzucchelli, S., Salvade, A., Tortora, P., Doglia, S. M., and Prosperi, D. (2011) Investigating the structural biofunctionality of antibodies conjugated to magnetic nanoparticles. Nanoscale 3, 387-390.

(46) Wawrzak, D., Metioui, M., Willems, E., Hendrickx, M., de Genst, E., and Leyns, L. (2007) Wnt3a binds to several sFRPs in the nanomolar range. Biochem. Biophys. Res. Commun. 357, 1119-1123.

(47) Cedervall, T., Lynch, I., Lindman, S., Berggard, T., Thulin, E., Nilsson, H., Dawson, K. A., and Linse, S. (2007) Understanding the nanoparticle-protein corona using methods to quantify exchange rates and affinities of proteins for nanoparticles. Proc. Natl. Acad. Sci. U.S.A. 104, 2050-2055.

(48) Lundqvist, M., Stigler, J., Elia, G., Lynch, I., Cedervall, T., and Dawson, K. A. (2008) Nanoparticle size and surface properties determine the protein corona with possible implications for biological impacts. Proc. Natl. Acad. Sci. U.S.A 105, 14265-14270.

(49) Blanchette, C. D., Fischer, N. O., Corzett, M., Bench, G., and Hoeprich, P. D. (2010) Kinetic Analysis of His-Tagged Protein Binding to Nickel-Chelating Nanolipoprotein Particles. Bioconj. Chem. 21, 1321-1330.

(50) Mourtas, S., Canovi, M., Zona, C., Aurilia, D., Niarakis, A., La Ferla, B., Salmona, M., Nicotra, F., Gobbi, M., and Antimisiaris, S. G. (2011) Curcumin-decorated 
nanoliposomes with very high affinity for amyloid-beta1-42 peptide. Biomaterials 32, 1635-1645.

(51) Choi, C. H., Alabi, C. A., Webster, P., and Davis, M. E. (2010) Mechanism of active targeting in solid tumors with transferrin-containing gold nanoparticles. Proc. Natl. Acad. Sci. U.S.A. 107, 1235-1240.

(52) Hillaireau, H., and Couvreur, P. (2009) Nanocarriers' entry into the cell: relevance to drug delivery. Cell Mol. Life Sci 66, 2873-2896.

(53) Wang, Y. C., Lee, Y. H., Huang, G. C., Lin, Y. H., Fan-Chiang, M. H., Chiu, A. W., and Huang, Y. L. (2006) Enhanced transformation and chemosensitivity of NIH3T3 cells transduced with hepatoma up-regulated protein. Biochem. Biophys. Res. Commun. 340, 244-249.

(54) Keyes, K., Cox, K., Treadway, P., Mann, L., Shih, C., Faul, M. M., and Teicher, B. A. (2002) An in vitro tumor model: analysis of angiogenic factor expression after chemotherapy. Cancer Res. 62, 5597-5602.

(55) Fessi, H., Puisieux, F., Devissaguet, J. P., Ammoury, N., and Benita, S. (1989) Nanocapsule formation by interfacial polymer deposition following solvent displacement. Int. J.Pharm. 55, R1-R4.

(56) Ellman, G. L. (1958) A colorimetric method for determining low concentrations of mercaptans. Arch. Biochem. Biophys. 74, 443-450.

(57) Othman, M., Bouchemal, K., Couvreur, P., and Gref, R. (2009) Microcalorimetric investigation on the formation of supramolecular nanoassemblies of associative polymers loaded with gadolinium chelate derivatives. Int. J. Pharm. 379, 218-225.

(58) Segura-Sanchez, F., Bouchemal, K., Lebas, G., Vauthier, C., Santos-Magalhaes, N. S., and Ponchel, G. (2009) Elucidation of the complexation mechanism between (+)-usnic 
acid and cyclodextrins studied by isothermal titration calorimetry and phase-solubility diagram experiments. J. Mol. Recognit. 22, 232-241.

(59) Uhlen, M., Oksvold, P., Fagerberg, L., Lundberg, E., Jonasson, K., Forsberg, M., Zwahlen, M., Kampf, C., Wester, K., Hober, S., Wernerus, H., Bjorling, L., and Ponten, F. (2010) Towards a knowledge-based Human Protein Atlas. Nat. Biotechnol. 28, 12481250. 
Table of Contents Graphic

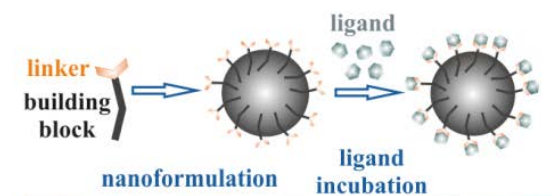

i) ligand coupling AFTER NP preparation

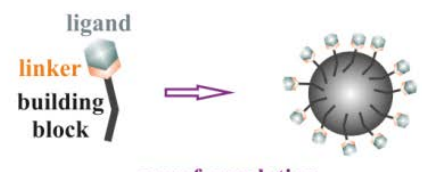

nanoformulation

ii) ligand coupling BEFORE NP preparation 